\title{
A STUDY TO DETERMINE FERTILIZATION RATE AND WATER QUANTITY SUITABLE FOR GROWTH AND QUALITY OF TUBEROSE PLANTS CULTIVATED IN SOME SOIL TYPES
}

Shahin, S.M. ${ }^{1}$; A.M.A. Mahmoud ${ }^{1}$ and M.Y.A. Abdalla ${ }^{2}$

(1) Botanical Gardens Res. Dept., Hort. Res. Inst., ARC, Giza, Egypt.

(2) Veget. and Flor. Dept., Fac. of Agric., Mansoura Univ.

\begin{abstract}
A study was consummated under the full sun at Orman Botanical Garden, Giza, Egypt during 2007 and 2008 seasons to find out the response of tuberose (Polianthes tuberosa L.) plants grown in $20-\mathrm{cm}$-diameter black polyethylene bags filled with $2.5 \mathrm{~kg}$ sandy, loamy or calcareous soils to the different quantities of irrigation water (100, 150 and $200 \mathrm{ml} /$ plant), as well as different rates of kristalon (0, 2 and $4 \mathrm{~g} /$ plant) and their interactions.

The obtained results indicated that sprouting date (days) was not affected by kristalon treatments, but was greatly reduced with increasing water amount to reach the minimum period in plants grown in either loamy or calcareous soil and irrigated with $150 \mathrm{ml}$ of water/plant, while for those grown in sandy soil, $200 \mathrm{ml} /$ plant was the best. Vegetative and root growth [expressed as leaf No./plant, leaf length $(\mathrm{cm})$, and fresh and dry weights $(\mathrm{g})$ of the leaves and roots], flowering [as No. days from planting to first flower open, spike length $(\mathrm{cm})$, rachis length $(\mathrm{cm})$, No. flowers/spike, No. spikes/plant and vase life (days)], as well as bulbs productivity [No. bulblets/plant and the fresh and dry weights $(\mathrm{g})$ of the replacement clump], were significantly improved in response to all individual treatments or their combinations applied in this study, with a notice that the best results in loamy and calcareous soils were obtained when the plants were irrigated with $150 \mathrm{ml}$ of water/plant and fertilized with $2 \mathrm{~g}$ of kristalon/plant, while in the sandy soil, that was true when the plants received the highest rates of both watering and fertilization $(200 \mathrm{ml}$ and $4 \mathrm{~g} / \mathrm{plant}$, respectively). The superiority in all previous traits was for planting in the loamy soil, followed by planting in calcareous one, and then planting in the sandy soil that gave the least records. A similar trend was also gained with regard to leaves content of chlorophyll $a, b$ and carotenoids (mg/g fresh weight), as well as the percentages of total carbohydrates, N, P and K.

Hence, it could be recommended to fertilize tuberose plants grown in sandy soil with $4 \mathrm{~g}$ kristalon/plant plus irrigation with $200 \mathrm{ml}$ of water/plant, while in the loamy and calcareous soils, it is preferable to fertilize with $2 \mathrm{~g} / \mathrm{plant}$ and irrigate with 150 $\mathrm{ml} /$ plant. It is also better to cultivate in loamy soil than cultivation in either sandy or calcareous ones.
\end{abstract}

\section{INTRODUCTION}

Polianthes tuberosa L., tuberose, which belongs to Fam. Agavaceae (Amaryllidaceae) is widely cultivated in the tropics and sub-tropics where it is esteemed for the purity and powerful fragrance of its blooms as a cut-flower and in gardens (Huxley et al., 1992).

Soil, water and nutrition are considered the most important elements in agriculture. So, the detection of water quantity and fertilization rate required for the healthy growth of plants when planted in special type of soil is regarded as one of the most vital points for which the scientific research sector exerts its utmost effort. In this regard, Auda et al. (2002) reported that 
keeping the soil moisture at $75 \%$ of field capacity gave the best tuberose vegetative growth and flowering quality. Munikrishnappa et al. (2002) indicated that fertigation of Polianthes tuberosa cv. Single plants with $80 \%$ recommended water-soluble NPK fertilizer $+0.1 \mathrm{~B}$ or $0.5 \% \mathrm{Zn}$ through sprinkler irrigation up to $75 \%$ of field capacity produced the greatest plant height, number of tillers, leaves and spikes/plant, leaf area, days to flowering, flowering duration, spike length, rachis length, floral diameter, number of florets/spike, fresh weight of spikes and flower yield. Sharma et al. (2003) revealed that irrigation of tuberose plants grown in sandy soil with sodic water significantly increased E. C. of the soil both with the addition of FYM and gypsum, while soil pH was decreased with the addition of gypsum only. The growth and flower yield were, however, significantly increased with the application of gypsum and FYM. Similarly, were those results recorded by Shahin et al. (2006) on sisal, Shahin et al. (2007) on Agave americana cv. Marginata and El Sayed et al. (2008) on Dodonaea viscosa.

Under water deficit conditions, plant growth is substantially reduced, while fertilization reduces the reverse effect, as it increases vegetative and root growth, flowers quality and improves the content of vital constituents (North and Nobel, 2000). This true was emphasized by Patel et al. (2006) who found that tuberose bulbs planted at $30 \times 20 \mathrm{~cm}$ and fertilized with $400 \mathrm{~kg}$ $\mathrm{N}+200 \mathrm{~kg}$ P/ha resulted the highest yield of spikes and bulb productivity. Application of $\mathrm{N}$ at $400 \mathrm{~kg} / \mathrm{ha}$ recorded significantly the highest values of vegetative and floral characters. Number of days to first flowering was advanced at the same level of $N$. The effect of $P$ was only significant on floral characters, viz. rachis length and number of florets/spike. Bulb yield in terms of clump weight (ton/ha) was also significant and $200 \mathrm{~kg} \mathrm{P} / \mathrm{ha}$ recorded higher values. Likewise, were those findings obtained by Padaganur et al. (2005), Sultana et al. (2006), Yadav (2007), Alan et al. (2007), Singh et al. (2007) and Muthoka and Muriithi (2008) on tuberose, Mahmoud (2007) on Antholyza and El-Sayed and El-Shal (2008) on Schefflera.

This trial, however aims to determine the optimum water quantity and fertilization rate with kristalon suitable for producing the best vegetative growth, flowering characteristics and bulbs productivity of tuberose plants grown in various soil textures.

\section{MATERIALS AND METHODS}

The present investigation was conducted at Orman Botanical Garden, Giza, Egypt under the full sun during the two consecutive seasons of 2007 and 2008 to study the effect of water quantity, soil texture, fertilization rate with kristalon and their interactions on growth, flowering, bulbs productivity and chemical composition of tuberose (Polianthes tuberosa L.) plant.

Tuberose bulbs cv. Double were planted on March, $1^{\text {st }}$ for both seasons in 20-cm-diameter black polyethylene bags filled with $2.5 \mathrm{~kg}$ of sandy, loamy or calcareous soils per bag at a depth of $5 \mathrm{~cm}$. The physical and chemical properties of the three used soils in the two seasons are shown in Table (a). The bulbs were used as a clump, as each one consisted of the mother bulb (at a size of 2.7-2.9 cm diameter and about 31.0-33.5 g weight) 
surrounded with 3-4 bulblets and dipped in a fungicide solution of orthocide for 15 minutes before planting. All bags were immediately irrigated after planting with $300 \mathrm{ml}$ of fresh water, but after one week, they were subjected to the following amounts of irrigation water: 100,150 and $200 \mathrm{ml} / \mathrm{plant}$. The amount of irrigation water was not added as a percent of field capacity (F.C.) due to its variability for the different media used in this study, which makes the addition of irrigation water as a percent of F.C. more difficult and more subjected to fall in error. Irrigation was done once every week during March and April, and two times weekly throughout the period from May to October

After one month from transplanting (on April, $1^{\text {st)}}$ ), the plants received the first batch of kristalon fertilizer (19:19:19 + micronutrients, manufactured by DSM Agrospecialists, Holland) as a soil drench at the rates of 0,2 and 4 $\mathrm{g} /$ plant. Two months later (on June, $1^{\text {st }}$ ), the second batch was added, while the third one was applied after flowering (on October, $1^{\text {st }}$ ).

Table (a): Physical and chemical properties of the used soils

\begin{tabular}{|c|c|c|c|}
\hline \multirow{2}{*}{ Soil properties } & \multicolumn{3}{|c|}{ Soil texture } \\
\hline & Sandy & Loamy & Calcareous \\
\hline Coarse sand (\%) & 89.03 & 10.18 & 8.63 \\
\hline Fine sand (\%) & 2.05 & 46.17 & 27.27 \\
\hline Silt (\%) & 0.40 & 19.53 & 34.70 \\
\hline Clay (\%) & 8.52 & 24.12 & 29.40 \\
\hline E. C. (dS/m) & 3.71 & 3.29 & 2.16 \\
\hline pH & 7.86 & 8.16 & 8.10 \\
\hline S. P. & 21.33 & 35.00 & 29.76 \\
\hline O. M. (\%) & 0.12 & 0.57 & 0.38 \\
\hline $\mathrm{Ca}^{++}(\mathrm{meq} / \mathrm{l})$ & 6.26 & 7.82 & 12.12 \\
\hline $\mathrm{Mg}^{++}(\mathrm{meq} / \mathrm{l})$ & 1.74 & 2.12 & 4.75 \\
\hline $\mathrm{K}^{+}(\mathrm{meq} / \mathrm{l})$ & 0.83 & 0.75 & 0.26 \\
\hline $\mathrm{Na}^{+}(\mathrm{meq} / \mathrm{l})$ & 7.16 & 15.40 & 6.73 \\
\hline $\mathrm{HCO}_{3}-(\mathrm{meq} / \mathrm{l})$ & 2.37 & 6.60 & 4.52 \\
\hline $\mathrm{Cl}^{-}$(meq/l) & 3.50 & 8.20 & 9.38 \\
\hline $\mathrm{SO}_{4}^{--}(\mathrm{meq} / \mathrm{l})$ & 10.12 & 11.29 & 9.96 \\
\hline
\end{tabular}

The split-split plot design was used with three replicates (Mead et al., 1993), as each replicate contained 5 plants. The main plot was water quantity, while the sub- and sub-sub- plots were devoted to soil texture and kristalon rate, respectively.

Data were recorded as follows: sprouting date (number of days from planting to sprouting) was registered at the beginning of the experiment, while during flowering; No. days from planting to first flower open (days), spike length $(\mathrm{cm})$, rachis length $(\mathrm{cm})$, No. flowers/spike, No. spikes/plant and vase life of spike (days) were monitored. At the end of the experiment in each season (on October, $31^{\text {st }}$ ), the following parameters were measured: leaf No./plant, leaf length $(\mathrm{cm})$, leaves and roots fresh and dry weights $(\mathrm{g})$, No. bulblets/plant and the fresh and dry weights $(\mathrm{g})$ of the replacement bulb. In fresh leaf samples taken from the middle part of the plants in the second 
season only, chlorophyll a, b and carotenoids contents ( $\mathrm{mg} / \mathrm{g}$ fresh weight) were determined according to Moran (1982), while in dry samples, the percentages of total carbohydrates (Herbert et al., 1971), N (Pregl, 1945), P (Luatanab and Olsen, 1965) and K (Jackson, 1973) were assessed.

Data were then tabulated and statistically analyzed according to SAS program (1994) using Duncan's Multiple Range Test (1955) to verify the significancy level among means of the different treatments and their interactions.

\section{RESULTS AND DISCUSSION}

Effect of water quantity, soil texture, kristalon level and their interactions on:

\section{1- Sprouting date}

Data in Table (1) show that sprouting date (days) was not affected by fertilization treatments with kristalon (since these treatments have not been added yet), but was greatly affected by both water quantity and soil texture in the two seasons. In general, increasing water amount significantly decreased the sprouting date, especially at the level of $150 \mathrm{ml} / \mathrm{plant}$ for plants grown in loamy and calcareous soils in both seasons, while for those grown in sandy one, $200 \mathrm{ml} / \mathrm{plant}$ was the best. The least number of days to sprouting was, however, recorded by plants cultivated in loamy soil, followed by those cultivated in calcareous one, and then those cultivated in sandy soil, which took the longest period to sprouting. This may be due to the least holding capacity of water in sandy soil, whereas in loamy and calcareous ones, such capacity is better. In addition, the content of organic matter and nutrients in the loam are usually higher (Table, a).

Table (1): Effect of soil texture, kristalon level, water quantity and their interactions on sprouting date of Polianthes tuberosa L. bulb during 2007 and 2008 seasons

\begin{tabular}{|c|c|c|c|c|c|c|c|c|c|}
\hline \multirow{3}{*}{$\begin{array}{c}\text { Soil } \\
\text { texture }\end{array}$} & \multirow{3}{*}{$\begin{array}{c}\text { Kristalon } \\
\text { level } \\
\text { (g/bag) }\end{array}$} & \multicolumn{4}{|c|}{ First season: 2007} & \multicolumn{4}{|c|}{ Second season: 2008} \\
\hline & & \multicolumn{8}{|c|}{ Water quantity (ml/bag) } \\
\hline & & 100 & 150 & 200 & Mean & 100 & 150 & 200 & Mean \\
\hline \multirow{4}{*}{ Sandy } & 0.0 & $35.68 \mathrm{a}$ & $33.17 a b$ & $30.00 \mathrm{~b}$ & $32.95 \mathrm{a}$ & $32.85 a$ & $30.54 b$ & $27.61 \mathrm{~b}$ & $30.33 a$ \\
\hline & 2.0 & $36.74 \mathrm{a}$ & $34.00 \mathrm{ab}$ & $30.67 b$ & $33.80 \mathrm{a}$ & $34.00 \mathrm{a}$ & 31.30 ba & $28.33 b$ & $31.21 \mathrm{a}$ \\
\hline & 4.0 & $36.70 \mathrm{a}$ & 33.46 ba & $31.48 b$ & $33.88 \mathrm{a}$ & $33.76 \mathrm{a}$ & $30.82 b$ & $29.00 \mathrm{~b}$ & $31.19 a$ \\
\hline & Mean & $36.37 \mathrm{a}$ & 33 & 30.7 & $4 \mathrm{a}$ & $33.54 \mathrm{a}$ & $30.89 \mathrm{~b}$ & $28.31 \mathrm{c}$ & $30.91 \mathrm{a}$ \\
\hline \multirow{4}{*}{ Loamy } & 0.0 & $17.82 \mathrm{gf}$ & 10.001 & $15.00 \mathrm{~h}$ & $15.44 \mathrm{c}$ & $16.40 \mathrm{e}$ & $12.83 \mathrm{~g}$ & $13.91 \mathrm{f}$ & $14.38 \mathrm{c}$ \\
\hline & 2.0 & $19.41 \mathrm{f}$ & $14.70 \mathrm{~h}$ & $16.33 \mathrm{~g}$ & $16.81 \mathrm{c}$ & $17.85 \mathrm{e}$ & $14.26 \mathrm{f}$ & $15.20 \mathrm{fe}$ & $15.77 \mathrm{c}$ \\
\hline & 4.0 & $17.98 \mathrm{gf}$ & $14.13 \mathrm{hi}$ & $15.76 \mathrm{gh}$ & $15.96 \mathrm{c}$ & $16.56 \mathrm{e}$ & $13.02 \mathrm{~g}$ & $15.11 \mathrm{fe}$ & $14.90 \mathrm{c}$ \\
\hline & Mean & $18.40 \mathrm{f}$ & $14.11 \mathrm{~h}$ & $15.70 \mathrm{~g}$ & $16.07 \mathrm{c}$ & $16.94 \mathrm{f}$ & $13.37 \mathrm{~h}$ & $14.74 \mathrm{~g}$ & $15.02 \mathrm{c}$ \\
\hline \multirow{4}{*}{ Calcareous } & 0.0 & $29.70 \mathrm{~b}$ & $22.30 \mathrm{e}$ & $25.00 \mathrm{~d}$ & $25.67 \mathrm{~b}$ & $28.33 b$ & $21.00 \mathrm{~d}$ & $23.31 \mathrm{c}$ & $24.21 b$ \\
\hline & 2.0 & $28.58 \mathrm{c}$ & $23.16 \mathrm{ed}$ & $26.10 \mathrm{dc}$ & $25.95 b$ & $27.70 \mathrm{cb}$ & $21.76 \mathrm{~d}$ & $24.03 c$ & $24.50 \mathrm{~b}$ \\
\hline & 4.0 & $29.00 \mathrm{~b}$ & $22.00 \mathrm{e}$ & $24.81 \mathrm{~d}$ & $25.27 b$ & $28.00 \mathrm{~b}$ & $21.10 d$ & $23.86 \mathrm{c}$ & $24.32 b$ \\
\hline & Mean & $29.09 c$ & $22.49 \mathrm{e}$ & $25.30 \mathrm{~d}$ & $25.63 b$ & $28.01 \mathrm{c}$ & $21.29 \mathrm{e}$ & $23.73 d$ & $24.34 b$ \\
\hline \multicolumn{2}{|c|}{ Water quantity mean } & $27.95 a$ & $23.38 \mathrm{~b}$ & $23.91 \mathrm{~b}$ &  & $26.16 \mathrm{a}$ & $21.85 b$ & $22.26 \mathrm{~b}$ & 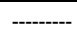 \\
\hline
\end{tabular}

* Means within a column or row having the same letters are not significantly different according to Duncan's Multiple Range Test (DMRT) at $5 \%$ level. 


\section{2- Vegetative and root growth parameters}

Similarly, vegetative and root growth were improved in response to all treatments and interactions employed in this study as shown in Tables (2, 3 and 4). However, the best results in loamy and calcareous soils were obtained when plants were irrigated with $150 \mathrm{ml}$ water/plant and fertilized with $2 \mathrm{~g}$ kristalon/plant, while in sandy soil, that was true when the plants were irrigated and fertilized with the highest rates of both water and kristalon (200 $\mathrm{ml}$ and $4 \mathrm{~g}$ per plant, respectively). The superiority in all vegetative and root growth parameters was for planting in loamy soil + irrigation with $150 \mathrm{ml}$ water/plant + fertilization with kristalon at $2 \mathrm{~g} / \mathrm{plant}$, as this combination gave the highest number of leaves/plant, the longest leaf (Table, 2) and the heaviest fresh and dry weights of leaves and roots comparing with all other treatments and combinations in the two seasons (Tables, 3 and 4).

The aforementioned results, however, may indicate the role of suitable amount of water in preventing the synthesis of abscisic acid (ABA), which negatively affects root growth, induces defoliation and may inhibit plant growth (Hoffman et al, 1999). Likewise, Dosmann et al. (1999) concluded that Katsura ornamental tree as a drought avoider that abscises its leaves to reduce transpirational water loss, is capable of quick refoliation after water becomes available due to having higher levels of acidic auxins, acidic and basic gibberellins and low levels of ABA, which might activate meristems and encourage cell division, elongation and enlargement that increase metabolites in the plant which is reflected on more growth and heavier plants. Stimulation of plant growth due to kristalon application would be reasonable since different nutrients usually activate vital processes, produce essential compounds as carbohydrates, proteins, hormones, enzymes and energyreserve material (North and Nobel, 2000). Besides, the presence of loam granules may improve structure and texture of the medium, increase cation exchange capacity and water holding capacity, which lead finally to increase water and nutrients uptake by plants and consequently activate vital processes necessary for more growth and good quality (Yadav, 2007). These results are in accordance with those of Auda et al. (2002), Sharma et al. (2003), Padaganur et al. (2005) and Alan et al. (2007) on tuberose, Shahin et al. (2006) on sisal and El-Sayed et al. (2008) on Dodonaea viscosa.

\section{3- Flowering parameters}

From data shown in Table (5), it is clear that number of days from planting to first flower open was progressively decreased with increasing of either water quantity or fertilization rate under the different used soil textures in the two seasons. However, the earliest flowering was noticed in plants grown in loamy soil compared to the other two ones, especially for plants irrigated with $150 \mathrm{ml}$ of water/plant and dressed with kristalon at $2 \mathrm{~g} / \mathrm{plant}$ level, as this combined treatment registered 76.43 days to flowering in the first season and 73.07 days in the second one. This may exhibit the role of both water and fertilizer when applied in optimum rate in accelerating vegetative growth and consequently precocity of flowering. 
Shahin, S.M. et al.

2 
J. Agric. Sci. Mansoura Univ., 34 (4), April, 2009

3 
Shahin, S.M. et al.

4 
Table (5): Effect of soil texture, kristalon level, water quantity and their interactions on number of days from planting to first flower open (days) of Polianthes tuberosa L. plant during 2007 and 2008 seasons

\begin{tabular}{|c|c|c|c|c|c|c|c|c|c|}
\hline \multirow{3}{*}{$\begin{array}{c}\text { Soil } \\
\text { texture }\end{array}$} & \multirow{3}{*}{$\begin{array}{c}\text { Kristalon } \\
\text { level } \\
\text { (g/bag) }\end{array}$} & \multicolumn{4}{|c|}{ First season: 2007} & \multicolumn{4}{|c|}{ Second season: 2008} \\
\hline & & \multicolumn{8}{|c|}{ Water quantity (ml/bag) } \\
\hline & & 100 & 150 & 200 & Mean & 100 & 150 & 200 & Mean \\
\hline \multirow{4}{*}{ Sandy } & 0.0 & $124.00 \mathrm{a}$ & $122.50 \mathrm{a}$ & $122.00 \mathrm{a}$ & $122.83 \mathrm{a}$ & $118.76 \mathrm{a}$ & $115.90 \mathrm{a}$ & $114.76 \mathrm{a}$ & $116.47 \mathrm{a}$ \\
\hline & 2.0 & $112.00 \mathrm{~b}$ & $106.07 \mathrm{c}$ & $96.80 \mathrm{ed}$ & $104.96 \mathrm{c}$ & $106.40 \mathrm{~b}$ & $101.16 \mathrm{c}$ & $93.69 \mathrm{e}$ & $100.42 b$ \\
\hline & 4.0 & $108.33 c$ & $98.58 \mathrm{ed}$ & $85.33 \mathrm{f}$ & $97.41 \mathrm{~d}$ & $102.91 \mathrm{c}$ & $93.10 \mathrm{e}$ & $81.85 \mathrm{~h}$ & $92.59 \mathrm{c}$ \\
\hline & Mean & $114.78 \mathrm{a}$ & $109.05 b$ & $101.38 \mathrm{~cd}$ & $108.40 \mathrm{a}$ & $109.36 \mathrm{a}$ & $103.39 \mathrm{~b}$ & $73 c$ & $103.16 \mathrm{a}$ \\
\hline \multirow{4}{*}{ Loamy } & & $116.10 \mathrm{~b}$ & $108.26 \mathrm{c}$ & $102.56 \mathrm{~d}$ & $108.97 b$ & $110.21 \mathrm{~b}$ & $102.85 \mathrm{c}$ & $98.74 \mathrm{~d}$ & $103.93 b$ \\
\hline & 2.0 & 97.50 ed & $76.43 \mathrm{~h}$ & $90.76 \mathrm{e}$ & $88.23 \mathrm{f}$ & $92.83 \mathrm{e}$ & $73.07 i$ & $85.50 \mathrm{~g}$ & $83.80 \mathrm{e}$ \\
\hline & 4.0 & 98.00 ed & $83.00 \mathrm{~g}$ & $80.33 \mathrm{~g}$ & $87.11 \mathrm{f}$ & $92.10 \mathrm{e}$ & 78.90 in & $81.33 \mathrm{~h}$ & $84.11 \mathrm{e}$ \\
\hline & Mean & $103.87 \mathrm{c}$ & $89.23 \mathrm{e}$ & $91.22 \mathrm{e}$ & $94.77 \mathrm{c}$ & $98.38 \mathrm{c}$ & $84.94 \mathrm{f}$ & $88.52 \mathrm{e}$ & $90.61 \mathrm{c}$ \\
\hline \multirow{4}{*}{ Calcareous } & 0.0 & $124.00 \mathrm{a}$ & $121.63 \mathrm{a}$ & $113.17 b$ & $119.60 \mathrm{ab}$ & $117.21 \mathrm{a}$ & $114.00 \mathrm{a}$ & $107.54 \mathrm{~b}$ & $112.92 \mathrm{ba}$ \\
\hline & 2.0 & 99.00 ed & $93.46 \mathrm{e}$ & $96.33 \mathrm{ed}$ & $96.26 \mathrm{~d}$ & 9505 ed & $89.36 \mathrm{f}$ & $90.20 \mathrm{f}$ & $91.54 \mathrm{c}$ \\
\hline & 4.0 & $99.33 \mathrm{ed}$ & $92.00 \mathrm{e}$ & $87.56 \mathrm{f}$ & $92.96 \mathrm{e}$ & $94.33 \mathrm{ed}$ & $87.40 \mathrm{fg}$ & $83.50 \mathrm{~g}$ & $88.41 \mathrm{~d}$ \\
\hline & Mean & $107.44 \mathrm{~b}$ & $102.36 \mathrm{c}$ & $99.02 d$ & $102.94 \mathrm{~b}$ & $102.20 \mathrm{~b}$ & $96.92 \mathrm{c}$ & $93.75 \mathrm{~d}$ & $97.62 \mathrm{~b}$ \\
\hline \multicolumn{2}{|c|}{ Water quantity mean } & $108.70 \mathrm{a}$ & $100.21 \mathrm{~b}$ & $97.21 \mathrm{c}$ & 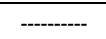 & $103.31 \mathrm{a}$ & $95.08 \mathrm{~b}$ & $93.00 \mathrm{c}$ & ------- \\
\hline
\end{tabular}

* Means within a column or row having the same letters are not significantly different according to Duncan's Multiple Range Test (DMRT) at $5 \%$ level.

A similar trend was also gained regarding spike length $(\mathrm{cm})$, rachis length $(\mathrm{cm})$, No. flowers/spike, No. spikes/plant and vase life of spikes in tap water (days) as shown in Tables (6, 7 and 8), where these characters were significantly improved by all treatments and combinations accomplished in such trial, with the prevalence of the combination between $150 \mathrm{ml} / \mathrm{plant}$ water level and $2 \mathrm{~g} /$ plant kristalon rate in the loamy soil, which gave the utmost high averages comparing with other treatments and their interactions in the two seasons.

These results could be interpreted and discussed as done before in case of vegetative and root growth parameters. Similar observations, however were also attained by Munikrishnappa et al. (2002), Sultana et al. (2006) and Singh et al. (2007) on tuberose.

\section{4- Bulbs productivity}

Data in Tables (9 and 10) reveal that No. bulblets/plant and the fresh and dry weights $(\mathrm{g})$ of the replacement bulb under the various soil textures used in the study were cumulatively increased with elevating of either water amount or fertilization rate. However, higher means in all previous measurements were gained from the combined treatments, especially at the highest levels of irrigation and fertilization in sandy and calcareous soils, while in the loam, that was true at the medium rates of both irrigation and fertilization. The highest records, on the other hand were obtained from planting in loamy soil plus irrigation and fertilization at the rates of $150 \mathrm{ml}$ and $2 \mathrm{~g}$ per plant, respectively, as this combination scored the highest values over all other individual treatments and combinations in both seasons. 
Shahin, S.M. et al.

6 
J. Agric. Sci. Mansoura Univ., 34 (4), April, 2009

7 
Shahin, S.M. et al.

8 
Table (9): Effect of soil texture, kristalon level, water quantity and their interactions on number of bulblets of Polianthes tuberosa $\mathrm{L}$. plant during 2007 and 2008 seasons

\begin{tabular}{|c|c|c|c|c|c|c|c|c|c|}
\hline \multirow{3}{*}{$\begin{array}{c}\text { Soil } \\
\text { texture }\end{array}$} & \multirow{3}{*}{$\begin{array}{c}\text { Kristalon } \\
\text { level } \\
\text { (g/bag) }\end{array}$} & \multicolumn{4}{|c|}{ First season: 2007} & \multicolumn{4}{|c|}{ Second season: 2008} \\
\hline & & \multicolumn{8}{|c|}{ Water quantity (ml/bag) } \\
\hline & & 100 & 150 & 200 & Mean & 100 & 150 & 200 & Mean \\
\hline \multirow{4}{*}{ Sandy } & 0.0 & $5.33 \mathrm{~g}$ & $6.50 \mathrm{fg}$ & $7.28 \mathrm{f}$ & $6.37 \mathrm{e}$ & $5.81 \mathrm{~h}$ & $7.09 \mathrm{~g}$ & $8.00 \mathrm{f}$ & $6.97 \mathrm{~d}$ \\
\hline & 2.0 & $8.00 \mathrm{e}$ & $8.91 \mathrm{ed}$ & $10.33 d c$ & $9.08 \mathrm{~cd}$ & $7.33 \mathrm{~g}$ & $8.76 \mathrm{fe}$ & $10.00 \mathrm{~d}$ & $8.70 \mathrm{c}$ \\
\hline & 4.0 & $9.90 \mathrm{~d}$ & $11.00 \mathrm{~cd}$ & $11.33 \mathrm{~cd}$ & $10.74 \mathrm{~b}$ & $8.56 \mathrm{fe}$ & $10.36 \mathrm{~d}$ & $9.59 \mathrm{e}$ & $9.50 \mathrm{~b}$ \\
\hline & Mean & $7.74 \mathrm{e}$ & $8.80 \mathrm{~d}$ & $9.65 \mathrm{ed}$ & $8.73 \mathrm{c}$ & $7.23 \mathrm{~d}$ & $8.74 \mathrm{c}$ & $9.20 \mathrm{~b}$ & $8.39 \mathrm{~b}$ \\
\hline \multirow{4}{*}{ Loamy } & 0.0 & $7.44 \mathrm{f}$ & $9.33 \mathrm{de}$ & $11.35 \mathrm{~cd}$ & $9.37 c$ & $7.00 \mathrm{~g}$ & $9.00 \mathrm{e}$ & $10.47 \mathrm{~d}$ & $8.82 \mathrm{c}$ \\
\hline & 2.0 & $10.21 \mathrm{dc}$ & $16.00 \mathrm{a}$ & $14.00 \mathrm{~b}$ & $13,40 \mathrm{a}$ & $8.78 \mathrm{fe}$ & $14.79 \mathrm{a}$ & 13.50ba & $12.36 \mathrm{a}$ \\
\hline & 4.0 & $12.61 \mathrm{cb}$ & $14.00 \mathrm{~b}$ & $13.33 \mathrm{bc}$ & $13.31 \mathrm{a}$ & $10.33 d$ & $11.28 \mathrm{c}$ & $12.70 \mathrm{~b}$ & $11.44 a b$ \\
\hline & Mean & $10.09 \mathrm{c}$ & $13.11 \mathrm{a}$ & $12.89 \mathrm{a}$ & $12.03 \mathrm{a}$ & $8.70 \mathrm{c}$ & $11.69 \mathrm{a}$ & $12.22 \mathrm{a}$ & $10.87 \mathrm{a}$ \\
\hline \multirow{4}{*}{ Calcareous } & 0.0 & $7.00 \mathrm{f}$ & $8.17 \mathrm{e}$ & $11.00 \mathrm{~cd}$ & $8.72 \mathrm{~d}$ & $7.00 \mathrm{~g}$ & $8.33 \mathrm{f}$ & $10.00 \mathrm{~d}$ & $8.44 \mathrm{c}$ \\
\hline & 2.0 & $9.00 \mathrm{ed}$ & $14.00 \mathrm{~b}$ & $14.50 \mathrm{~b}$ & $12.50 a b$ & $8.76 \mathrm{fe}$ & $12.89 \mathrm{~b}$ & $13.33 \mathrm{ba}$ & $11.66 a b$ \\
\hline & 4.0 & $12.00 \mathrm{c}$ & $13.10 b c$ & $12.67 \mathrm{cb}$ & $12.59 a b$ & $10.00 \mathrm{~d}$ & $12.10 \mathrm{~b}$ & $11.86 \mathrm{c}$ & $11.32 \mathrm{ba}$ \\
\hline & Mean & $9.33 \mathrm{dc}$ & $11.76 \mathrm{~b}$ & 12.72ab & $11.27 \mathrm{~b}$ & $8.59 \mathrm{c}$ & $11.11 a b$ & $11.73 \mathrm{a}$ & $10.47 \mathrm{a}$ \\
\hline \multicolumn{2}{|c|}{ Water quantity mean } & $9.05 b$ & $11.22 \mathrm{a}$ & $11.75 \mathrm{a}$ & ------ & $8.17 \mathrm{~b}$ & $10.51 \mathrm{a}$ & $11.05 \mathrm{a}$ &  \\
\hline
\end{tabular}

* Means within a column or row having the same letters are not significantly different according to Duncan's Multiple Range Test (DMRT) at $5 \%$ level.

These results may indicate the role of kristalon on supplying the growing buds with the required nutrients necessary for accelerating growth, and hence forming more bulblets. Moreover, kristalon as a complete fertilizer may promote the synthesis of more reserve foods stored in the new-formed bulbs and bulblets and make them relatively greater. On the same line, were those findings postulated by Auda et al. (2002) and Patel et al. (2006) on tuberose, Shahin et al. (2006) on sisal and Mahmoud (2007) on Antholyza.

\section{5- Chemical composition}

It is evident from data in Table (11) that leaf contents of chlorophyll a, $\mathrm{b}$ and carotenoids ( $\mathrm{mg} / \mathrm{g}$ fresh weight) were augmentatively increased with few exceptions, as water supply or kristalon rate were increased. All combinations induced also a marked improvement in pigments content in the leaves of treated plants. In sandy soil, the best content was noticed when the plants received the highest levels of both water and fertilization. In the loam, that was true when the plants treated with the medium levels of water and kristalon, whereas in the calcareous soil, the best records achieved in plants irrigated with the medium water level $(150 \mathrm{ml} /$ plant) and fertilized with the highest rate of kristalon ( $4 \mathrm{~g} /$ plant).

Similarly, the percentages of total carbohydrates, N, P and K in the leaves (Table,12) were augmented as a result of the various individual treatments or combinations applied in this work. However, the best results were recorded by plants grown in loamy soil, followed by these cultivated in calcareous one, and then those cultured in the sand. 
Shahin, S.M. et al.

10 
J. Agric. Sci. Mansoura Univ., 34 (4), April, 2009 
Shahin, S.M. et al.

12 
Under sandy soil conditions, the highest values were registered by the highest levels of watering and fertilization, while under loamy soil conditions, the medium rates of irrigation and dressing scored the best means. In calcareous soil, the best means were found due to the medium and high levels of watering and fertilization, as they gave averages closely near together.

These results may be explained by the combined effect of both water and the complete fertilizer, irrespective of soil type, on supplying tuberose plants with their required water and nutrients necessary for accelerating biosynthesis processes which increase the content of vital constituents in plant tissues (North and Nobel, 2000). Similar observations were also obtained by Auda et al. (2002) on tuberose, Shahin et al. (2006) on sisal and El-Sayed and El-Shal (2008) on Schefflera.

According to the aforestated results, it could be recommended to fertilize tuberose plants grown in sandy soil with $4 \mathrm{~g}$ of kristalon/plant and irrigation with $200 \mathrm{ml}$ of water/plant, while in loamy and calcareous soils, it is preferable to fertilize with $2 \mathrm{~g} / \mathrm{plant}$ and irrigate with $150 \mathrm{ml} /$ plant.

\section{REFERENCES}

Alan, O.; Y. Gunen; S. Ceylan and E. Gunen (2007). Effect of nitrogen application on flower yield, some quality characteristics and leaf mineral content in tuberose. Anadolu, 17 (1): 43-57.

Auda. M. S; M. H. El-Shakhs and S. M. Shahin (2002). Response of Polianthes tuberosa L. to different moisture stress levels and gibberellic acid. Egypt. J. Appl. Sci., 17 (7): 708-727.

Dosmann, M. S.; J. K. Iles and W. R. Graves (1999). Drought avoidance in Katsura by drought-induced leaf abscission and rapid refoliation. HortScience, 34 (5): 871-874.

Duncan, D. B. (1955). Multiple range and multiple F-tests.J.Biometrics,11: 1 42.

El-Sayed, Boshra A. and S. El-Shal (2008). Effect of growing media and humic acid on Schefflera quality. J. Agric. Sci., Mansoura Univ., 33 (1): 371-381.

El-Sayed, Boshra A.; Y. L. Eliwa Naglaa and S. M. Shahin (2008). Response of Dodonaea viscosa (L.) Jacq. transplants to paclobutrazol spray and irrigation periods. Minufiya J. Agric. Res., 33 (1): 105-118.

Herbert, D.; P. J. Philips and R. E. Strange (1971). Determination of total carbohydrates. Methods in Microbiology, 5 (8): 290-344.

Hoffman, A.; C. Shock and E. Feibert (1999). Taxane and ABA production in yew under different soil water regimes. HortScience, 34 (5): 882-885.

Huxley, A.; M. Griffiths and M. Levy (1992). The New Royal Hort. Soc. Dict. Gar., The Stockton Press, New York, 257 Park Avenue South, NY 100 10, USA. Vol. 1, 815pp.

Jackson, M.L. (1973). Soil Chemical Analysis. Prentice-Hall of India Private Limited M-97, New Delhi, India, 498pp.

Luatanab, F. S. and S. R. Olsen (1965). Test of an ascorbic acid method for determining phosphorus in water and $\mathrm{NaHCO}_{3}$ extracts from soil. Soil Sci. Soc. Amer. Proc, 29: 677-678. 
Mahmoud, A. M. A. (2007). Response of Chasmanthe aethiopica (L.) N. E. $\mathrm{Br}$. plants to foliar spray with kinetin and kristalon. J. Agric. Sci., Mansoura Univ., 32 (7): 5517-5528.

Mead, R.; R. N. Curnow and A. M. Harted (1993). Statistical Methods in Agriculture and Experimental Biology, $2^{\text {nd }}$ Ed., Chapman \& Hall Ltd., London, $335 \mathrm{pp}$.

Moran, R. (1982). Formula for determination of chlorophyllous pigment extracted with N-N-dimethyl formamid. Plant Physiol., 69:1376-81.

Munikrishnappa, P. M.; M. C. Gowda; A. A. Farooqi and Y. A. Reddy (2002). Fertigation studies in tuberose cv. Single. Indian J. Hort., 59 (1): 106110.

Muthoka, N. M. and A. N. Muriithi (2008). Smallholder summer flower production in Kenya: a myth or a prospect?. Acta Hort., 766: 219-223

North, G. B. and P. S. Nobel (2000). Heterogeneity in water availability alters cellular development and hydraulic conductivity along roots of a desert succulent. Annals of Botany, 85(2):247-255.

Padaganur, V. G.; A. N. Mokashi and V. S. Patil (2005). Flowering, flower quality and yield of tuberose as influenced by vermicompost, FYM and fertilizers. Karnataka J. Agric. Sci., 18 (3): 729-734.

Patel, M. M.; P. B. Parmar and B. R. Parmar (2006). Effect of nitrogen, phosphorus and spacing on growth and flowering in tuberose cv. Single. J. Ornam. Hort., 9 (4): 286-289.

Pregl, F. (1945). Quantitative Organic Micro-Analysis, $4^{\text {th }}$ Ed., J. and A. Churchill Ltd., London, pp. 203-209.

SAS Institute (1994). SAS/STAT User's Guide: Statistics. Vers. 6.04, $4^{\text {th }}$ Ed., SAS Institute Inc., Cary, N. C., USA.

Shahin, S. M.; N. D. Manoly and S. Ahmed Samira (2006). Response of sisal (Agave sisalana Perinne) to chemical fertilization and water supply. Minufiya J. Agric. Res., 31 (1): 107-124.

Shahin, S. M.; A. M. A. Mahmoud and M. Y. A. Abdalla (2007). Response of Agave americana L. Cv. Marginata plant to different media and water quantities. J. Agric. Sci., Mansoura Univ., 32 (11): 9227-9240.

Sharma, S. K.; A. Tikkoo; A. K. Kapoor and S. S. Dahiya (2003). Effect of sodic water, FYM and gypsum on soil properties and performance of tuberose. Haryana J. Hort. Sci., 32 (3/4): 219-221.

Singh, B.; R. Sirvastava and R. Chandra (2007). Effect of Panchgavya and Manchurian Mushroom tea on floral characters in tuberose cv. Pearl Double. J. Ornam. Hort., 10 (4): 250-254.

Sultana, S.; E. N. Khan; M. A. Haque; S. Akhter and S. Noor (2006). Effect of NPK on growth and flowering in tuberose. J. Subtropical Agric. Res. \& Dev., 4 (2): 111-113.

Yadav, P. K. (2007). Effect of nitrogen and phosphorus on growth and flowering of tuberose cv. Shringar. Progressive Agric., 7 (1/2): 189. 
دراسـة لتحديد معدل التسميا وكميـة الميـاه الملائمـة لنمو وجودة نباتـات التيبروز



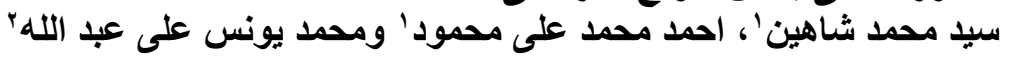

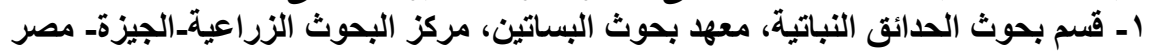

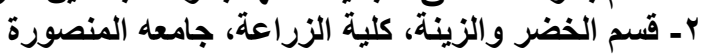

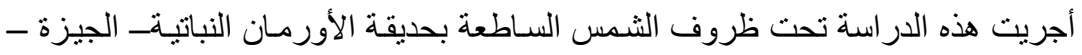

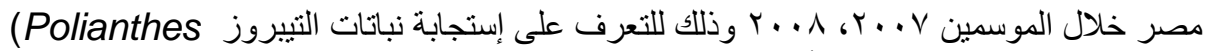

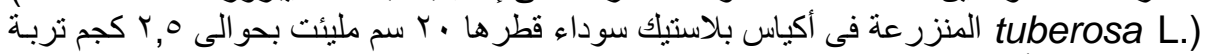

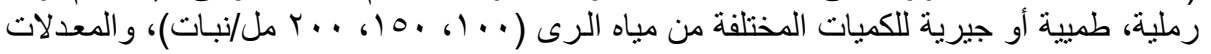

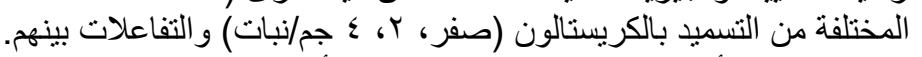

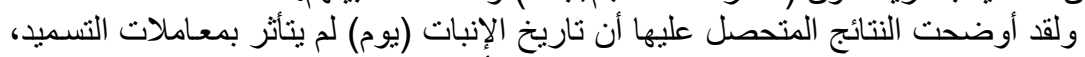

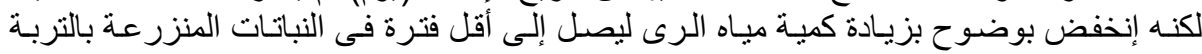

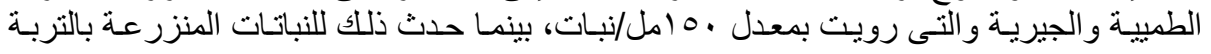

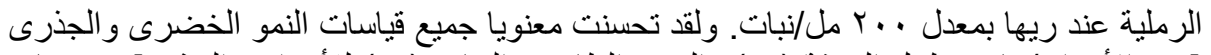





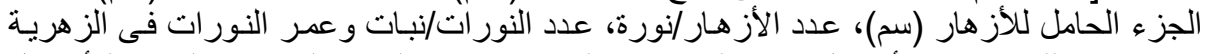





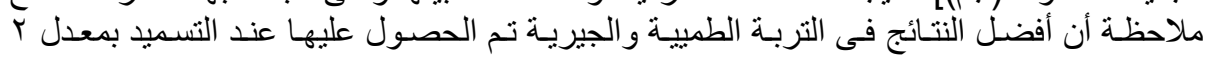

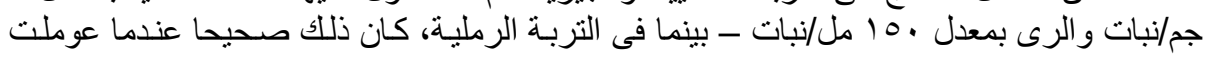



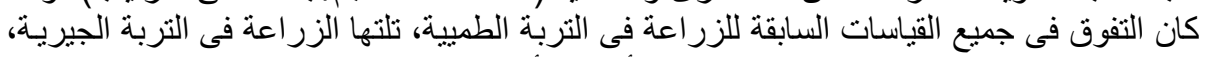

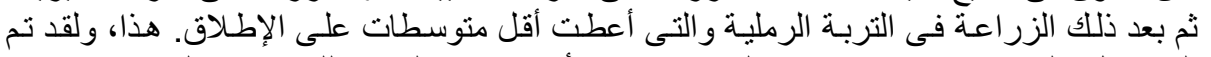

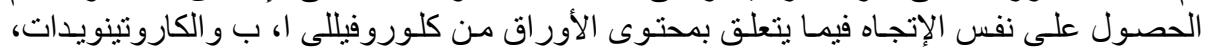





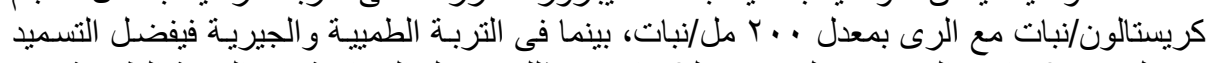

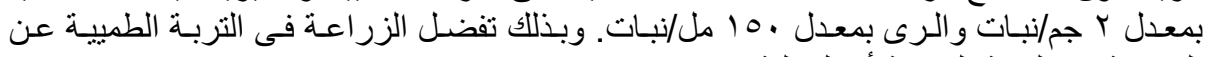
الزراعة فى التربة الجيرية أو الرملية. 
Shahin, S.M. et al. 
J. Agric. Sci. Mansoura Univ., 34 (4), April, 2009 
Table (2): Effect of soil texture, kristalon level, water quantity and their interactions on leaf number and length of Polianthes tuberosa L. plant during 2007 and 2008 seasons

\begin{tabular}{|c|c|c|c|c|c|c|c|c|c|c|c|c|c|c|c|c|c|}
\hline \multirow{4}{*}{$\begin{array}{c}\text { Soil } \\
\text { texture }\end{array}$} & \multirow{4}{*}{$\begin{array}{c}\text { Kristalon } \\
\text { level } \\
\text { (g/bag) }\end{array}$} & \multicolumn{8}{|c|}{ Leaf No./plant } & \multicolumn{8}{|c|}{ Leaf length $(\mathrm{cm})$} \\
\hline & & \multicolumn{4}{|c|}{ First season: 2007} & \multicolumn{4}{|c|}{ Second season: 2008} & \multicolumn{4}{|c|}{ First season: 2007} & \multicolumn{4}{|c|}{ Second season: 2008} \\
\hline & & \multicolumn{16}{|c|}{ Water quantity (ml/bag) } \\
\hline & & 100 & 150 & 200 & Mean & 100 & 150 & 200 & Mean & 100 & 150 & 200 & Mean & 100 & 150 & 200 & Mean \\
\hline \multirow{4}{*}{ Sandy } & 0 & 21.831 & $25.79 \mathrm{k}$ & $28.12 \mathrm{j}$ & $25.25 \mathrm{e}$ & $23.10 \mathrm{I}$ & $26.50 \mathrm{j}$ & $29.70 \mathrm{ji}$ & $26.43 \mathrm{e}$ & 24.311 & $31.00 \mathrm{in}$ & $33.91 \mathrm{in}$ & $29.74 \mathrm{e}$ & $25.60 \mathrm{k}$ & $32.90 \mathrm{i}$ & $35.00 \mathrm{~h}$ & $31.17 f$ \\
\hline & 2.0 & $23.90 \mathrm{lk}$ & $30.47 \mathrm{hi}$ & $36.00 \mathrm{f}$ & $30.12 \mathrm{~d}$ & $25.33 \mathrm{k}$ & $32.00 \mathrm{hi}$ & $38.66 \mathrm{f}$ & $31.80 \mathrm{~d}$ & $27.46 \mathrm{jk}$ & $36.85 \mathrm{gh}$ & $40.10 \mathrm{f}$ & $34.80 \mathrm{~d}$ & $28.76 \mathrm{kj}$ & $39.00 \mathrm{gf}$ & $40.33 \mathrm{f}$ & $36.03 \mathrm{e}$ \\
\hline & 4.0 & $24.00 \mathrm{k}$ & $30.78 \mathrm{hi}$ & $37.18 \mathrm{fe}$ & $30.65 \mathrm{~d}$ & $25.50 \mathrm{k}$ & $32.54 \mathrm{~h}$ & $39.22 \mathrm{e}$ & $32.42 \mathrm{~d}$ & $28.60 \mathrm{j}$ & $35.96 \mathrm{~h}$ & $41.50 \mathrm{e}$ & $35.35 \mathrm{~d}$ & $30.21 \mathrm{j}$ & $37.67 \mathrm{~g}$ & 43.50ed & $37.13 \mathrm{~d}$ \\
\hline & ean & $23.24 \mathrm{f}$ & $29.01 \mathrm{e}$ & $33.77 \mathrm{~d}$ & $28.67 \mathrm{c}$ & $24.64 \mathrm{f}$ & $30.35 \mathrm{e}$ & $35.66 \mathrm{~d}$ & $30.22 \mathrm{c}$ & $26.79 \mathrm{f}$ & $34.60 \mathrm{e}$ & $38.50 \mathrm{c}$ & $33.30 \mathrm{c}$ & $28.19 \mathrm{e}$ & $36.52 \mathrm{~d}$ & $39.61 \mathrm{c}$ & 34.78 \\
\hline \multirow{4}{*}{ Loamy } & 0 & $31.06 \mathrm{~h}$ & $36,71 \mathrm{f}$ & $37.13 \mathrm{fe}$ & $34.97 \mathrm{c}$ & $33.00 \mathrm{~h}$ & $38.90 \mathrm{fe}$ & $39.30 \mathrm{e}$ & $37.07 \mathrm{c}$ & $32.15 \mathrm{i}$ & $42.00 \mathrm{e}$ & $41.30 \mathrm{fe}$ & $38.48 \mathrm{c}$ & $33.26 \mathrm{i}$ & 43.70ed & $43.78 \mathrm{ed}$ & $40.25 \mathrm{~cd}$ \\
\hline & 2.0 & $35.86 \mathrm{~g}$ & $48.00 \mathrm{a}$ & $44.16 \mathrm{c}$ & $42.67 \mathrm{a}$ & $37.95 \mathrm{f}$ & $50.00 \mathrm{a}$ & $45.60 \mathrm{c}$ & $44.52 \mathrm{a}$ & $37.98 \mathrm{gf}$ & $53.00 \mathrm{a}$ & $48.76 \mathrm{~b}$ & $46.58 \mathrm{a}$ & $39.30 \mathrm{gf}$ & $55.10 \mathrm{a}$ & $51.56 \mathrm{~b}$ & 48.65 \\
\hline & 4.0 & $36.90 \mathrm{f}$ & $46.20 \mathrm{~b}$ & $47.69 \mathrm{a}$ & $43.60 \mathrm{a}$ & $40.00 \mathrm{ed}$ & $47.70 \mathrm{~b}$ & $48.76 \mathrm{ab}$ & $45.49 \mathrm{a}$ & $38.50 \mathrm{gf}$ & $45.74 \mathrm{c}$ & $49.80 \mathrm{ba}$ & $44.68 \mathrm{ab}$ & $40.81 \mathrm{f}$ & $47.80 \mathrm{c}$ & $51.96 \mathrm{~b}$ & $46.86 \mathrm{ab}$ \\
\hline & Mean & $34.61 \mathrm{c}$ & $43.64 \mathrm{a}$ & $42.99 \mathrm{a}$ & $40.41 \mathrm{a}$ & $36.98 \mathrm{c}$ & $45.53 \mathrm{a}$ & $44.55 \mathrm{a}$ & $42.36 \mathrm{a}$ & $36.21 \mathrm{~d}$ & $46.91 \mathrm{a}$ & $46.62 \mathrm{a}$ & $43.25 \mathrm{a}$ & $37.79 \mathrm{dc}$ & $48.87 \mathrm{a}$ & $49.10 \mathrm{a}$ & $45.25 \mathrm{a}$ \\
\hline \multirow{4}{*}{ Calce } & & $30.29 \mathrm{i}$ & $36.72 \mathrm{f}$ & $37.00 \mathrm{fe}$ & $34.67 \mathrm{c}$ & $31.50 \mathrm{i}$ & $38.00 \mathrm{f}$ & $40.00 \mathrm{ed}$ & $36.50 \mathrm{c}$ & $31.10 \mathrm{i}$ & $39.02 \mathrm{fg}$ & $40.33 \mathrm{f}$ & $36.82 \mathrm{~cd}$ & $32.00 \mathrm{ij}$ & $40.33 \mathrm{f}$ & $42.40 \mathrm{e}$ & $38.24 \mathrm{~d}$ \\
\hline & 2.0 & $35.67 \mathrm{~g}$ & $41.33 \mathrm{~d}$ & $39.02 \mathrm{de}$ & $38.67 \mathrm{~b}$ & $36.10 \mathrm{~g}$ & $42.40 \mathrm{~d}$ & 40.76de & $39.75 \mathrm{~b}$ & $37.48 \mathrm{~g}$ & $46.10 \mathrm{c}$ & $42.10 \mathrm{e}$ & $41.89 \mathrm{~b}$ & $38.10 \mathrm{~g}$ & $48.76 \mathrm{c}$ & $44.25 \mathrm{~d}$ & $43.70 \mathrm{~b}$ \\
\hline & 4.0 & $36.10 \mathrm{f}$ & $38.26 \mathrm{e}$ & $38.50 \mathrm{ed}$ & $37.62 \mathrm{~b}$ & $38.20 \mathrm{f}$ & $39.46 \mathrm{e}$ & $40.00 \mathrm{ed}$ & $39.22 \mathrm{~b}$ & $38.00 \mathrm{gf}$ & $43.50 \mathrm{~d}$ & $40.76 \mathrm{f}$ & $40.75 b c$ & $38.00 \mathrm{~g}$ & $45.00 \mathrm{~d}$ & $41.88 \mathrm{fe}$ & $41.63 \mathrm{c}$ \\
\hline & Mean & $34.02 \mathrm{c}$ & $38.77 \mathrm{~b}$ & $38.17 \mathrm{~b}$ & $36.99 \mathrm{~b}$ & $35.27 \mathrm{~d}$ & $39.95 \mathrm{~b}$ & $40.25 \mathrm{~b}$ & $38.49 \mathrm{~b}$ & $35.53 \mathrm{~d}$ & $42.87 \mathrm{~b}$ & $41.06 \mathrm{~b}$ & $39.82 \mathrm{~b}$ & $36.03 \mathrm{~d}$ & $44.70 \mathrm{~b}$ & $42.84 \mathrm{~b}$ & $41.19 \mathrm{~b}$ \\
\hline \multicolumn{2}{|c|}{ Water quantity mean } & $30.62 b$ & $37.14 \mathrm{a}$ & $38.31 \mathrm{a}$ & ------ & $32.30 \mathrm{~b}$ & $38.61 \mathrm{a}$ & $40.15 \mathrm{a}$ & ------ & $32.84 \mathrm{~b}$ & $41.46 \mathrm{a}$ & $42.06 \mathrm{a}$ & ------ & $34.00 \mathrm{~b}$ & $43.36 \mathrm{a}$ & $43.85 \mathrm{a}$ & ------ \\
\hline
\end{tabular}

${ }^{*}$ Means within a column or row having the same letters are not significantly different according to Duncan's Multiple Range Test (DMRT) at $5 \%$ level. 
Table (3): Effect of soil texture, kristalon level, water quantity and their interactions on fresh and dry weights of Polianthes tuberosa L. leaves during 2007 and 2008 seasons

\begin{tabular}{|c|c|c|c|c|c|c|c|c|c|c|c|c|c|c|c|c|c|}
\hline \multirow{4}{*}{$\begin{array}{c}\text { Soil } \\
\text { texture }\end{array}$} & \multirow{4}{*}{$\begin{array}{c}\text { Kristalon } \\
\text { level } \\
\text { (g/bag) }\end{array}$} & \multicolumn{8}{|c|}{ Leaves fresh weight (g) } & \multicolumn{8}{|c|}{ Leaves dry weight (g) } \\
\hline & & \multicolumn{4}{|c|}{ First season: 2007} & \multicolumn{4}{|c|}{ Second season: 2008} & \multicolumn{4}{|c|}{ First season: 2007} & \multicolumn{4}{|c|}{ Second season: 2008} \\
\hline & & \multicolumn{16}{|c|}{ Water quantity (ml/bag) } \\
\hline & & 100 & 150 & 200 & Mean & 100 & 150 & 200 & Mean & 100 & 150 & 200 & Mean & 100 & 150 & 200 & Mean \\
\hline \multirow{4}{*}{ Sandy } & 0.0 & $36.50 \mathrm{~g}$ & $40.00 \mathrm{~g}$ & $47.28 \mathrm{f}$ & $41.26 \mathrm{~g}$ & $39.60 \mathrm{~h}$ & $42.80 \mathrm{~h}$ & $50.61 \mathrm{~g}$ & $44.34 \mathrm{f}$ & $6.52 \mathrm{f}$ & $7.25 \mathrm{fe}$ & $8.54 \mathrm{ed}$ & $7.44 \mathrm{f}$ & $6.96 \mathrm{~g}$ & $7.88 \mathrm{fg}$ & 9.10 ef & $7.95 \mathrm{e}$ \\
\hline & 2.0 & $42.76 \mathrm{gf}$ & $50.82 \mathrm{f}$ & $66.18 \mathrm{ed}$ & $53.25 \mathrm{f}$ & $45.76 \mathrm{~g}$ & $54.36 \mathrm{f}$ & $70.33 \mathrm{e}$ & $56.80 \mathrm{e}$ & $7.00 \mathrm{f}$ & $8.16 \mathrm{e}$ & $10.50 \mathrm{~d}$ & $8.55 \mathrm{e}$ & $7.50 \mathrm{fg}$ & $8.78 \mathrm{f}$ & $11.24 \mathrm{ed}$ & $9.17 \mathrm{~d}$ \\
\hline & 4.0 & $48.50 \mathrm{f}$ & $55.30 \mathrm{fe}$ & $60.27 \mathrm{e}$ & $54.69 \mathrm{f}$ & $51.36 \mathrm{fg}$ & $58.90 \mathrm{f}$ & $64.50 \mathrm{fe}$ & $58.25 \mathrm{e}$ & $7.76 \mathrm{fe}$ & $8.50 \mathrm{ed}$ & $8.90 \mathrm{de}$ & $8.39 \mathrm{e}$ & $8.25 \mathrm{f}$ & 9.00 ef & 9.30 ef & $8.85 \mathrm{de}$ \\
\hline & Mean & $42.59 \mathrm{~h}$ & $48.71 \mathrm{~g}$ & $57.91 \mathrm{f}$ & $49.73 \mathrm{c}$ & $45.55 \mathrm{~h}$ & $52.02 \mathrm{~g}$ & $61.81 \mathrm{f}$ & $53.13 \mathrm{c}$ & $7.09 \mathrm{f}$ & $7.97 \mathrm{f}$ & $9.31 \mathrm{e}$ & $8.13 \mathrm{c}$ & $7.57 \mathrm{~h}$ & $8.53 \mathrm{~g}$ & $9.88 \mathrm{f}$ & $8.66 \mathrm{c}$ \\
\hline \multirow{4}{*}{ Loamy } & 0.0 & $61.58 \mathrm{e}$ & $79.10 \mathrm{dc}$ & $86.20 \mathrm{c}$ & $75.63 \mathrm{~d}$ & $64.13 \mathrm{fe}$ & $80.50 \mathrm{~d}$ & $92.10 \mathrm{c}$ & $78.91 \mathrm{~cd}$ & $10.24 \mathrm{~d}$ & $13.20 \mathrm{dc}$ & $14.00 \mathrm{c}$ & $12.48 \mathrm{~d}$ & $10.91 \mathrm{e}$ & $13.96 \mathrm{~d}$ & $15.00 \mathrm{c}$ & $13.29 \mathrm{c}$ \\
\hline & 2.0 & $92.15 \mathrm{cb}$ & $120.33 a$ & $99.57 \mathrm{~b}$ & $104.02 \mathrm{a}$ & $96.41 \mathrm{cb}$ & $129.00 \mathrm{a}$ & $105.91 \mathrm{~b}$ & $110.44 a$ & $15.31 \mathrm{cb}$ & $21.30 \mathrm{a}$ & $16.53 \mathrm{~b}$ & $17.71 \mathrm{a}$ & $15.76 \mathrm{c}$ & $21.80 \mathrm{a}$ & $17.10 \mathrm{~b}$ & $18.22 \mathrm{a}$ \\
\hline & 4.0 & $85.00 \mathrm{c}$ & $103.56 \mathrm{~b}$ & $92.10 \mathrm{cb}$ & $93.55 \mathrm{~b}$ & $91.00 \mathrm{c}$ & $110.21 b$ & $98.50 \mathrm{cb}$ & $99.90 \mathrm{~b}$ & $13.88 \mathrm{c}$ & $16.81 \mathrm{~b}$ & $15.10 \mathrm{cb}$ & $15.26 \mathrm{~b}$ & $14.33 \mathrm{c}$ & $17.21 \mathrm{~b}$ & $16.03 \mathrm{cb}$ & $15.86 \mathrm{~b}$ \\
\hline & Mean & $79.58 \mathrm{~d}$ & $101.00 \mathrm{a}$ & $92.62 \mathrm{~b}$ & $91.07 \mathrm{a}$ & $83.85 \mathrm{~d}$ & $106.57 a$ & $98.84 \mathrm{~b}$ & $96.42 \mathrm{a}$ & $13.14 d c$ & $17.10 \mathrm{a}$ & $15.21 \mathrm{~b}$ & $15.15 \mathrm{a}$ & $13.67 \mathrm{~d}$ & $17.66 \mathrm{a}$ & $16.04 \mathrm{~b}$ & $15.79 \mathrm{a}$ \\
\hline \multirow{4}{*}{ Calcareous } & 0.0 & $58.70 \mathrm{e}$ & $71.36 \mathrm{~d}$ & $75.41 \mathrm{dc}$ & $68.49 \mathrm{e}$ & $62.81 \mathrm{fe}$ & $76.40 \mathrm{ed}$ & $80.67 \mathrm{~d}$ & $73.29 \mathrm{~d}$ & $10.43 \mathrm{~d}$ & $12.67 \mathrm{dc}$ & $13.41 \mathrm{dc}$ & $12.17 d$ & $10.58 \mathrm{e}$ & $13.50 \mathrm{~d}$ & $14.36 \mathrm{c}$ & $12.81 \mathrm{~cd}$ \\
\hline & 2.0 & 63.72ed & $96.78 \mathrm{~b}$ & $81.97 \mathrm{~cd}$ & $80.82 \mathrm{c}$ & $68.16 \mathrm{e}$ & $102.72 b$ & $90.00 \mathrm{c}$ & $86.96 \mathrm{c}$ & $11.30 \mathrm{~d}$ & $17.22 \mathrm{~b}$ & $14.50 \mathrm{c}$ & $14.34 \mathrm{c}$ & $12.10 \mathrm{de}$ & $18.20 \mathrm{~b}$ & $15.00 \mathrm{c}$ & $15.10 \mathrm{~b}$ \\
\hline & 4.0 & $71.31 \mathrm{~d}$ & $87.03 \mathrm{c}$ & $80.33 \mathrm{~cd}$ & $79.56 \mathrm{c}$ & $76.10 \mathrm{ed}$ & $93.07 \mathrm{c}$ & $85.95 \mathrm{~d}$ & $85.04 \mathrm{c}$ & $12.70 \mathrm{dc}$ & $15.46 \mathrm{cb}$ & $14.30 \mathrm{c}$ & $14.15 \mathrm{c}$ & $13.50 \mathrm{~d}$ & $16.00 \mathrm{cb}$ & $15.33 c$ & $14.94 \mathrm{bc}$ \\
\hline & Mean & $64.58 \mathrm{e}$ & $85.06 \mathrm{c}$ & $79.24 \mathrm{~d}$ & $76.29 \mathrm{~b}$ & $69.02 \mathrm{e}$ & $90.73 \mathrm{c}$ & $85.54 \mathrm{~d}$ & $81.76 \mathrm{~b}$ & $11.48 \mathrm{~d}$ & $15.12 b$ & $14.07 \mathrm{c}$ & $13.55 \mathrm{~b}$ & $12.06 \mathrm{e}$ & $15.90 \mathrm{~b}$ & $14.90 \mathrm{c}$ & $14.28 \mathrm{~b}$ \\
\hline \multicolumn{2}{|c|}{ Water quantity mean } & $62.25 b$ & $78.26 \mathrm{a}$ & $76.59 \mathrm{a}$ & ----- & $66.14 \mathrm{~b}$ & $83.11 \mathrm{a}$ & $82.06 \mathrm{a}$ & ----- & $10.57 \mathrm{~b}$ & $13.40 \mathrm{a}$ & $12.86 \mathrm{a}$ & ---- & $11.10 \mathrm{~b}$ & $14.03 \mathrm{a}$ & $13.61 \mathrm{a}$ & ----- \\
\hline
\end{tabular}
$5 \%$ level. 
Table (4): Effect of soil texture, kristalon level, water quantity and their interactions on fresh and dry weights of Polianthes tuberosa L. roots during 2007 and 2008 seasons

\begin{tabular}{|c|c|c|c|c|c|c|c|c|c|c|c|c|c|c|c|c|c|}
\hline \multirow{4}{*}{$\begin{array}{l}\text { Soil } \\
\text { texture }\end{array}$} & \multirow{4}{*}{$\begin{array}{c}\text { Kristalon } \\
\text { level } \\
\text { (g/bag) }\end{array}$} & \multicolumn{8}{|c|}{ Roots fresh weight (g) } & \multicolumn{8}{|c|}{ Roots dry weight (g) } \\
\hline & & \multicolumn{4}{|c|}{ First season: 2007} & \multicolumn{4}{|c|}{ Second season: 2008} & \multicolumn{4}{|c|}{ First season: 2007} & \multicolumn{4}{|c|}{ Second season: 2008} \\
\hline & & \multicolumn{16}{|c|}{ Water quantity (ml/bag) } \\
\hline & & 100 & 150 & 200 & Mean & 100 & 150 & 200 & Mean & 100 & 150 & 200 & Mean & 100 & 150 & 200 & Mean \\
\hline \multirow{4}{*}{ Sandy } & 0 & $8.54 \mathrm{i}$ & $9.18 \mathrm{in}$ & $9.96 \mathrm{~h}$ & $9.23 \mathrm{~d}$ & $9.21 \mathrm{~h}$ & $9.96 \mathrm{~h}$ & $10.81 \mathrm{~g}$ & $9.99 \mathrm{~d}$ & $67 \mathrm{f}$ & $2.88 \mathrm{f}$ & 3.29 ef & $2.95 \mathrm{~d}$ & $.81 \mathrm{f}$ & $3.03 \mathrm{fe}$ & $3.27 \mathrm{e}$ & $3.04 \mathrm{~d}$ \\
\hline & 2.0 & $9.33 \mathrm{~h}$ & $10.08 \mathrm{~h}$ & $10.53 \mathrm{hg}$ & $9.98 \mathrm{~d}$ & $9.87 \mathrm{~h}$ & $10.91 \mathrm{~g}$ & $11.40 \mathrm{gf}$ & $10.73 d$ & 3.03 fe & $3.75 \mathrm{e}$ & $3.94 \mathrm{e}$ & $3.57 \mathrm{~cd}$ & 3.18 ef & $4.00 \mathrm{ed}$ & $4.18 \mathrm{~d}$ & $3.79 \mathrm{~cd}$ \\
\hline & 4.0 & $9.58 \mathrm{~h}$ & $10.89 \mathrm{hg}$ & $11.37 \mathrm{~g}$ & $10.61 \mathrm{c}$ & $10.37 \mathrm{hg}$ & $11.15 \mathrm{~g}$ & $11.56 \mathrm{gf}$ & $11.01 \mathrm{c}$ & $3.00 \mathrm{fe}$ & 3.41 ef & $4.36 \mathrm{ed}$ & $3.59 \mathrm{~cd}$ & $3.25 \mathrm{e}$ & $3.52 \mathrm{e}$ & $4.65 \mathrm{~d}$ & $3.81 \mathrm{~cd}$ \\
\hline & ean & $9.15 \mathrm{f}$ & $10.05 \mathrm{e}$ & $10.62 \mathrm{e}$ & $9.94 \mathrm{~b}$ & $9.82 \mathrm{~d}$ & $10.66 \mathrm{c}$ & $11.26 \mathrm{c}$ & $10.58 \mathrm{~b}$ & $2.90 \mathrm{~d}$ & $3.35 \mathrm{c}$ & $3.86 \mathrm{c}$ & $3.37 \mathrm{~b}$ & $3.08 \mathrm{~d}$ & $3.52 \mathrm{c}$ & $4.03 \mathrm{c}$ & $3.55 \mathrm{~b}$ \\
\hline \multirow{4}{*}{ Loamy } & 0.0 & $11.72 \mathrm{~g}$ & $12.68 \mathrm{fe}$ & $13.71 \mathrm{e}$ & $12.70 \mathrm{~b}$ & $12.64 \mathrm{f}$ & $13.61 \mathrm{e}$ & $14.80 \mathrm{~d}$ & $13.68 \mathrm{~b}$ & $4.96 \mathrm{de}$ & $5.37 \mathrm{~d}$ & $5.80 \mathrm{dc}$ & $5.38 \mathrm{~b}$ & $5.00 \mathrm{~d}$ & $5.76 \mathrm{c}$ & $6.18 \mathrm{~b}$ & $5.65 b$ \\
\hline & 2.0 & $12.50 \mathrm{f}$ & $22.38 \mathrm{a}$ & $16.12 \mathrm{dc}$ & $17.00 \mathrm{a}$ & $13.46 \mathrm{e}$ & $19.76 \mathrm{a}$ & $17.39 \mathrm{c}$ & $16.87 \mathrm{a}$ & $5.36 \mathrm{~d}$ & $8.55 \mathrm{a}$ & $6.20 \mathrm{c}$ & $6.70 \mathrm{a}$ & $5.79 \mathrm{c}$ & $7.28 \mathrm{a}$ & $6.70 \mathrm{~b}$ & $6.59 \mathrm{a}$ \\
\hline & 4.0 & $14.58 \mathrm{~d}$ & $19.35 \mathrm{~b}$ & $17.83 \mathrm{c}$ & $17.25 \mathrm{a}$ & $14.50 \mathrm{~d}$ & $18.76 \mathrm{a}$ & $18.00 \mathrm{~b}$ & $17.09 \mathrm{a}$ & $5.78 \mathrm{dc}$ & $7.66 \mathrm{~b}$ & $7.00 \mathrm{bc}$ & $6.81 \mathrm{a}$ & $5.37 \mathrm{~cd}$ & $7.10 \mathrm{a}$ & $7.06 \mathrm{a}$ & $6.51 \mathrm{a}$ \\
\hline & Mean & $12.93 \mathrm{~d}$ & $18.14 \mathrm{a}$ & $15.89 \mathrm{c}$ & $15.65 \mathrm{a}$ & $13.53 \mathrm{~b}$ & $17.38 \mathrm{a}$ & $16.73 \mathrm{a}$ & $15.88 \mathrm{a}$ & $5.37 \mathrm{~b}$ & $7.19 \mathrm{a}$ & $6.33 \mathrm{ba}$ & $6.30 \mathrm{a}$ & $5.39 \mathrm{~b}$ & $6.71 \mathrm{a}$ & $6.65 \mathrm{a}$ & $6.25 \mathrm{a}$ \\
\hline \multirow{4}{*}{ Calcareous } & 0.0 & $11.55 \mathrm{~g}$ & $11.78 \mathrm{~g}$ & $12.80 \mathrm{fe}$ & $12.04 \mathrm{~b}$ & $12.42 \mathrm{f}$ & $12.75 \mathrm{f}$ & 13.81ed & $12.99 \mathrm{~b}$ & $3.70 \mathrm{e}$ & $3.89 \mathrm{e}$ & $4.12 \mathrm{ed}$ & $3.90 \mathrm{c}$ & $3.98 \mathrm{ed}$ & $4.11 \mathrm{de}$ & $4.39 \mathrm{~d}$ & $4.16 \mathrm{c}$ \\
\hline & 2.0 & $12.46 \mathrm{f}$ & $20.75 \mathrm{ab}$ & $16.90 \mathrm{~cd}$ & $16.70 \mathrm{a}$ & $13.43 \mathrm{e}$ & $18.47 \mathrm{ab}$ & $17.82 \mathrm{c}$ & $16.57 \mathrm{a}$ & $5.42 \mathrm{~d}$ & $8.31 \mathrm{a}$ & $7.33 \mathrm{~b}$ & $7.02 \mathrm{a}$ & $5.51 \mathrm{~cd}$ & $7.30 \mathrm{a}$ & $7.08 \mathrm{a}$ & $6.63 \mathrm{a}$ \\
\hline & 4.0 & $13.87 \mathrm{e}$ & $18.40 \mathrm{~b}$ & $17.24 \mathrm{c}$ & $16.50 \mathrm{a}$ & $14.00 \mathrm{~d}$ & $17.90 \mathrm{~b}$ & $17.36 \mathrm{c}$ & $16.42 \mathrm{a}$ & $5.67 \mathrm{dc}$ & $7.51 \mathrm{~b}$ & $7.03 \mathrm{bc}$ & $6.74 \mathrm{a}$ & $5.70 \mathrm{c}$ & $7.21 \mathrm{a}$ & $6.87 \mathrm{~b}$ & $6.59 \mathrm{a}$ \\
\hline & Mean & $12.63 \mathrm{~d}$ & $16.98 \mathrm{~b}$ & $15.65 \mathrm{c}$ & $15.08 \mathrm{a}$ & $13.28 \mathrm{~b}$ & $16.37 \mathrm{a}$ & $16.33 \mathrm{a}$ & $15.33 \mathrm{a}$ & $4.93 \mathrm{~b}$ & $6.57 a b$ & $6.16 \mathrm{ba}$ & $5.89 \mathrm{a}$ & $5.06 \mathrm{~b}$ & $6.21 \mathrm{ab}$ & $6.11 \mathrm{ab}$ & $5.79 \mathrm{a}$ \\
\hline \multicolumn{2}{|c|}{ Water quantity mean } & $11.57 \mathrm{~b}$ & $15.06 \mathrm{a}$ & $14.05 \mathrm{a}$ & ------ & $12.21 \mathrm{~b}$ & $14.80 \mathrm{a}$ & $14.77 \mathrm{a}$ & ------ & $4.40 \mathrm{~b}$ & $5.70 \mathrm{a}$ & $5.45 \mathrm{a}$ & $\mid$ & $4.51 \mathrm{~b}$ & $5.48 \mathrm{a}$ & $5.60 \mathrm{a}$ & ------- \\
\hline
\end{tabular}

* Means within a column or row having the same letters are not significantly different according to Duncan's Multiple Range Test (DMRT) at $5 \%$ level. 
Table (6): Effect of soil texture, kristalon level, water quantity and their interactions on spike and rachis lengths of Polianthes tuberosa L. plant during 2007 and 2008 seasons

\begin{tabular}{|c|c|c|c|c|c|c|c|c|c|c|c|c|c|c|c|c|c|}
\hline \multirow{4}{*}{$\begin{array}{l}\text { Soil } \\
\text { texture }\end{array}$} & \multirow{4}{*}{$\begin{array}{c}\text { Kristalon } \\
\text { level } \\
\text { (g/bag) }\end{array}$} & \multicolumn{8}{|c|}{ Spike length (cm) } & \multicolumn{8}{|c|}{ Rachis length (cm) } \\
\hline & & \multicolumn{4}{|c|}{ First season: 2007} & \multicolumn{4}{|c|}{ Second season: 2008} & \multicolumn{4}{|c|}{ First season: 2007} & \multicolumn{4}{|c|}{ Second season: 2008} \\
\hline & & & & & & & & Wate & er quan & tity $(\mathrm{ml} /$ & I/bag) & & & & & & \\
\hline & & 100 & 150 & 200 & Mean & 100 & 150 & 200 & Mean & 100 & 150 & 200 & Mean & 100 & 150 & 200 & Mean \\
\hline \multirow{4}{*}{ Sandy } & 0.0 & $31.00 \mathrm{~h}$ & $33.00 \mathrm{gh}$ & $35.50 \mathrm{~g}$ & $33.17 \mathrm{~g}$ & $33.41 \mathrm{~h}$ & $35.42 \mathrm{hg}$ & $37.80 \mathrm{~g}$ & $35.54 \mathrm{~g}$ & $8.00 \mathrm{e}$ & $8.33 \mathrm{ed}$ & $8.76 \mathrm{~d}$ & $8.36 \mathrm{c}$ & $8.00 \mathrm{~d}$ & $8.00 \mathrm{~d}$ & $8.67 \mathrm{dc}$ & $8.22 \mathrm{~d}$ \\
\hline & 2.0 & $31.80 \mathrm{~h}$ & $34.10 \mathrm{gh}$ & $37.33 \mathrm{gf} \mid 3$ & $34.41 \mathrm{~g}$ & $34.36 \mathrm{~h}$ & $37.10 \mathrm{~g}$ & $38.03 \mathrm{~g}$ & $36.50 \mathrm{gf}$ & $8.64 d$ & $8.90 \mathrm{~d}$ & $9.33 \mathrm{c}$ & $8.96 \mathrm{c}$ & $8.50 \mathrm{dc}$ & $8.83 \mathrm{dc}$ & $9.36 \mathrm{c}$ & $8.90 \mathrm{~d}$ \\
\hline & 4.0 & $33.48 \mathrm{gh}$ & $35.78 \mathrm{~g}$ & \begin{tabular}{|l|}
$39.00 \mathrm{f}$ \\
\end{tabular} & $36.09 \mathrm{f}$ & $35.50 \mathrm{hg}$ & $36.18 \mathrm{hg}$ & $41.33 \mathrm{f}$ & $37.67 \mathrm{f}$ & $8.78 \mathrm{~d}$ & $9.26 \mathrm{c}$ & $10.00 \mathrm{cb}$ & $9.35 \mathrm{~b}$ & $8.90 \mathrm{~cd}$ & $9.33 c$ & $10.21 \mathrm{~b}$ & $9.48 \mathrm{c}$ \\
\hline & Mean & $32.09 \mathrm{~g}$ & $34.29 \mathrm{f}$ & $37.28 \mathrm{e}$ & $34.56 \mathrm{c}$ & $34.42 \mathrm{~h}$ & $36.23 \mathrm{~g}$ & $39.05 \mathrm{f}$ & $36.57 \mathrm{c}$ & $8.47 \mathrm{c}$ & $8.83 \mathrm{c}$ & $9.36 \mathrm{~b}$ & $8.89 \mathrm{~b}$ & $8.47 \mathrm{~d}$ & $8.72 \mathrm{~d}$ & $9.41 \mathrm{c}$ & $8.87 \mathrm{~b}$ \\
\hline \multirow{4}{*}{ Loamy } & 0.0 & $38.14 \mathrm{f}$ & $40.81 \mathrm{fe}$ & $43.67 \mathrm{e}$ & $40.87 \mathrm{~d}$ & $40.16 \mathrm{f}$ & $41.80 \mathrm{f}$ & $46.50 \mathrm{e}$ & $42.82 \mathrm{~d}$ & $8.79 \mathrm{~d}$ & $9.40 \mathrm{c}$ & $10.14 \mathrm{~b}$ & $9.44 \mathrm{~b}$ & $9.40 \mathrm{c}$ & $10.11 \mathrm{~b}$ & $11.00 \mathrm{ba}$ & $10.17 \mathrm{~b}$ \\
\hline & 2.0 & $47.72 \mathrm{~d}$ & $70.00 \mathrm{a}$ & $50.00 \mathrm{c}$ & $55.91 \mathrm{a}$ & $48.70 \mathrm{~d}$ & $64.50 \mathrm{a}$ & $54.00 \mathrm{c}$ & $55.73 \mathrm{a}$ & $9.31 \mathrm{c}$ & $14.00 \mathrm{a}$ & $13.10 \mathrm{a}$ & $12.14 \mathrm{a}$ & $10.03 \mathrm{~b}$ & $12.78 \mathrm{a}$ & $12.46 \mathrm{a}$ & $11.76 \mathrm{a}$ \\
\hline & 4.0 & $45.81 \mathrm{~d}$ & $54.31 \mathrm{~b}$ & $49.50 \mathrm{~cd}$ & $49.87 \mathrm{~b}$ & $48.33 \mathrm{~d}$ & $58.31 \mathrm{~b}$ & $53.00 \mathrm{c}$ & $53.21 \mathrm{~b}$ & $10.87 \mathrm{~b}$ & $012.33 \mathrm{a}$ & $12.65 \mathrm{a}$ & $11.95 \mathrm{a}$ & 11.10ab & $011.35 a$ & $11.70 \mathrm{a}$ & $11.38 \mathrm{a}$ \\
\hline & Mean & $43.89 \mathrm{c}$ & $55.04 \mathrm{a}$ & $47.72 \mathrm{~b}$ & $48.88 \mathrm{a}$ & $45.73 d$ & $54.87 \mathrm{a}$ & $51.17 \mathrm{~b}$ & $50.59 \mathrm{a}$ & $9.66 \mathrm{~b}$ & $11.91 \mathrm{a}$ & $11.96 \mathrm{a}$ & $11.18 \mathrm{a}$ & $10.18 \mathrm{~b}$ & $11.41 \mathrm{a}$ & $11.72 \mathrm{a}$ & $11.10 \mathrm{a}$ \\
\hline \multirow{4}{*}{ Calcareous } & 0.0 & $36.12 \mathrm{~g}$ & $38.70 \mathrm{f}$ & $41.60 \mathrm{ef}$ & $38.81 \mathrm{e}$ & $37.10 \mathrm{~g}$ & $41.07 \mathrm{f}$ & 43.76 ef & $40.64 \mathrm{e}$ & $8.51 \mathrm{~d}$ & $9.20 \mathrm{c}$ & $10.00 \mathrm{cb}$ & $9.24 b$ & $9.00 \mathrm{~cd}$ & $9.73 \mathrm{cb}$ & $9.96 \mathrm{bc}$ & $9.56 \mathrm{c}$ \\
\hline & 2.0 & $39.00 \mathrm{f}$ & $51.28 \mathrm{c}$ & $47.35 \mathrm{~d}$ & $45.88 \mathrm{dc}$ & 43.00 ef & $55.60 \mathrm{~b}$ & $49.81 \mathrm{~d}$ & $49.47 \mathrm{c}$ & $9.36 \mathrm{c}$ & $12.83 \mathrm{a}$ & $12.50 \mathrm{a}$ & $11.56 \mathrm{a}$ & $9.47 \mathrm{c}$ & $13.00 \mathrm{a}$ & $12.14 \mathrm{a}$ & $11.54 \mathrm{a}$ \\
\hline & 4.0 & $44.51 \mathrm{e}$ & $50.33 \mathrm{c}$ & $46.76 \mathrm{~d}$ & $47.20 \mathrm{c}$ & $46.10 \mathrm{e}$ & $51.00 \mathrm{c}$ & $49.00 \mathrm{~d}$ & $48.70 \mathrm{c}$ & $10.67 b$ & \begin{tabular}{ll|}
0 & $11.28 \mathrm{ba}$ \\
\end{tabular} & $12.00 \mathrm{a}$ & $11.32 \mathrm{ab}$ & $10.81 \mathrm{~b}$ & $11.50 \mathrm{a}$ & $11.78 \mathrm{a}$ & $11.36 \mathrm{a}$ \\
\hline & Mean & $39.88 \mathrm{~d}$ & $46.77 b$ & $45.24 \mathrm{~b}$ & $43.96 \mathrm{~b}$ & $42.07 \mathrm{e}$ & $49.22 \mathrm{c}$ & $47.52 d c$ & $46.27 \mathrm{~b}$ & $9.51 \mathrm{~b}$ & $11.10 a b$ & $11.50 \mathrm{a}$ & $10.71 \mathrm{a}$ & $9.76 \mathrm{cb}$ & $11.41 \mathrm{a}$ & $11.29 \mathrm{a}$ & $10.82 \mathrm{a}$ \\
\hline \multicolumn{2}{|c|}{ Water quantity mean } & $38.62 \mathrm{c}$ & $45.37 \mathrm{a}$ & $43.41 \mathrm{~b}$ & ----- & $40.74 b$ & $46,77 a$ & $45.91 \mathrm{a}$ & \begin{tabular}{|c|} 
\\
\end{tabular} & $9.21 \mathrm{~b}$ & $10.61 \mathrm{a}$ & $10.94 \mathrm{a}$ & ----- & $9.47 \mathrm{~b}$ & $10.51 \mathrm{a}$ & $10.81 a$ & --.-- \\
\hline
\end{tabular}


Table (7): Effect of soil texture, kristalon level, water quantity and their interactions on number of flowers per spike and number of spikes per Polianthes tuberosa L. plant during 2007 and 2008 seasons

\begin{tabular}{|c|c|c|c|c|c|c|c|c|c|c|c|c|c|c|c|c|c|}
\hline \multirow{4}{*}{$\begin{array}{c}\text { Soil } \\
\text { texture }\end{array}$} & \multirow{4}{*}{$\begin{array}{c}\text { Kristalon } \\
\text { level } \\
\text { (g/bag) }\end{array}$} & \multicolumn{8}{|c|}{ No. flowers/spike } & \multicolumn{8}{|c|}{ No. spikes/plant } \\
\hline & & \multicolumn{4}{|c|}{ First season: 2007} & \multicolumn{4}{|c|}{ Second season: 2008} & \multicolumn{4}{|c|}{ First season: 2007} & \multicolumn{4}{|c|}{ Second season: 2008} \\
\hline & & \multicolumn{16}{|c|}{ Water quantity (ml/bag) } \\
\hline & & 100 & 150 & 200 & Mean & 100 & 150 & 200 & Mean & 100 & 150 & 200 & Mean & 100 & 150 & 200 & Mean \\
\hline \multirow{4}{*}{ Sandy } & 0 & $8.00 \mathrm{f}$ & $8.00 \mathrm{f}$ & $8.00 \mathrm{f}$ & $8.00 \mathrm{~d}$ & $8.00 \mathrm{e}$ & $8.00 \mathrm{e}$ & $8.00 \mathrm{e}$ & $8.00 \mathrm{e}$ & $1.00 \mathrm{e}$ & $1.00 \mathrm{e}$ & $1.76 \mathrm{~d}$ & $1.25 \mathrm{~d}$ & $1.00 \mathrm{e}$ & $1.00 \mathrm{e}$ & $1.56 \mathrm{ed}$ & $1.19 \mathrm{e}$ \\
\hline & 2.0 & $8.00 \mathrm{f}$ & $9.00 \mathrm{e}$ & $10.00 \mathrm{~d}$ & $9.00 \mathrm{c}$ & $8.00 \mathrm{e}$ & $9.00 \mathrm{~d}$ & $10.76 \mathrm{c}$ & $9.25 d$ & $1.33 \mathrm{ed}$ & $2.00 \mathrm{c}$ & $2.46 \mathrm{cb}$ & $1.93 \mathrm{c}$ & $1.33 \mathrm{ed}$ & $2.00 \mathrm{~d}$ & $2.26 \mathrm{dc}$ & $1.86 \mathrm{~d}$ \\
\hline & 4.0 & $8.00 \mathrm{f}$ & $9.00 \mathrm{e}$ & $12.00 \mathrm{c}$ & $9.67 \mathrm{c}$ & $8.00 \mathrm{e}$ & $10.98 \mathrm{cb}$ & $12.00 \mathrm{~b}$ & $10.33 \mathrm{c}$ & $1.76 \mathrm{~d}$ & $2.00 \mathrm{c}$ & $3.00 \mathrm{~b}$ & $2.25 \mathrm{bc}$ & $2.00 \mathrm{~d}$ & $2.00 \mathrm{~d}$ & $3.00 \mathrm{~b}$ & $2.33 \mathrm{c}$ \\
\hline & lean & $00 \mathrm{~d}$ & $8.67 \mathrm{dc}$ & $10.00 \mathrm{c}$ & $8.89 \mathrm{c}$ & $8.00 \mathrm{e}$ & $9.33 \mathrm{dc}$ & $10.25 \mathrm{c}$ & $19 \mathrm{c}$ & $1.36 \mathrm{c}$ & $1.67 \mathrm{cb}$ & $2.41 \mathrm{ba}$ & $1.81 \mathrm{c}$ & $1.44 \mathrm{~d}$ & $1.67 \mathrm{c}$ & $2.27 \mathrm{cb}$ & $1.79 \mathrm{c}$ \\
\hline \multirow{4}{*}{ Loamy } & 0.0 & $8.00 \mathrm{f}$ & $9.00 \mathrm{e}$ & $10.00 \mathrm{~d}$ & $9.00 \mathrm{c}$ & $8.00 \mathrm{e}$ & $9.76 \mathrm{~cd}$ & $10.33 \mathrm{c}$ & $9.36 \mathrm{~d}$ & $1.68 \mathrm{~d}$ & $2.00 \mathrm{c}$ & $2.00 \mathrm{c}$ & $1.89 \mathrm{c}$ & $1.76 \mathrm{de}$ & $2.00 \mathrm{~d}$ & $2.33 \mathrm{c}$ & $2.03 \mathrm{cc}$ \\
\hline & 2.0 & $10.00 \mathrm{~d}$ & $16.00 \mathrm{a}$ & $14.00 \mathrm{~b}$ & $13.33 \mathrm{a}$ & $9.76 \mathrm{~cd}$ & $14.00 \mathrm{a}$ & $14.00 \mathrm{a}$ & $12.59 \mathrm{a}$ & $2.33 \mathrm{cb}$ & $4.10 \mathrm{a}$ & $3.00 \mathrm{~b}$ & $3.14 \mathrm{a}$ & $2.33 \mathrm{c}$ & $4.47 \mathrm{a}$ & $3.30 \mathrm{~b}$ & $3.37 \mathrm{a}$ \\
\hline & 4.0 & $12.00 \mathrm{c}$ & $14.00 \mathrm{~b}$ & $14.00 \mathrm{~b}$ & $13.33 \mathrm{a}$ & $12.00 \mathrm{~b}$ & $13.00 \mathrm{ba}$ & $13.00 \mathrm{ba}$ & $12.67 \mathrm{a}$ & $3.00 \mathrm{~b}$ & $3.00 \mathrm{~b}$ & $2.67 \mathrm{bc}$ & $2.89 \mathrm{ab}$ & $3.00 \mathrm{~b}$ & $3.33 \mathrm{~b}$ & $3.67 \mathrm{ba}$ & $3.33 \mathrm{a}$ \\
\hline & Mean & $10.00 \mathrm{c}$ & $13.00 \mathrm{a}$ & $12.67 \mathrm{a}$ & $11.89 \mathrm{a}$ & $9.92 \mathrm{c}$ & $12.25 \mathrm{a}$ & $12.44 \mathrm{a}$ & $11.54 \mathrm{a}$ & $2.34 \mathrm{ba}$ & $3.03 \mathrm{a}$ & $2.56 \mathrm{ab}$ & $2.64 \mathrm{a}$ & $2.36 \mathrm{bc}$ & $3.27 \mathrm{a}$ & $3.10 \mathrm{a}$ & $2.91 \mathrm{a}$ \\
\hline \multirow{4}{*}{ Calcareous } & 0.0 & $8.00 \mathrm{f}$ & $9.00 \mathrm{e}$ & $10.00 \mathrm{~d}$ & $9.00 \mathrm{c}$ & $8.00 \mathrm{e}$ & $9.00 \mathrm{~d}$ & $10.00 \mathrm{c}$ & $9.00 \mathrm{~d}$ & $1.33 \mathrm{ed}$ & $1.67 \mathrm{~d}$ & $1.67 \mathrm{~d}$ & $1.56 \mathrm{~cd}$ & $1.33 \mathrm{ed}$ & $1.33 \mathrm{ed}$ & $1.93 \mathrm{~d}$ & $1.53 \mathrm{de}$ \\
\hline & 2.0 & $9.00 \mathrm{e}$ & $13.00 \mathrm{cb}$ & $12.00 \mathrm{c}$ & $11.33 \mathrm{~b}$ & $9.00 \mathrm{~d}$ & $12.00 \mathrm{~b}$ & $11.78 \mathrm{cb}$ & $10.93 \mathrm{bc}$ & $1.76 \mathrm{~d}$ & $3.00 \mathrm{~b}$ & $3.00 \mathrm{~b}$ & $2.59 \mathrm{~b}$ & $1.76 \mathrm{de}$ & $3.38 \mathrm{~b}$ & $3.26 \mathrm{~b}$ & $2.80 \mathrm{~b}$ \\
\hline & 4.0 & $10.00 \mathrm{~d}$ & $12.00 \mathrm{c}$ & $12.00 \mathrm{c}$ & $11.33 \mathrm{~b}$ & $10.33 \mathrm{c}$ & $12.00 \mathrm{~b}$ & $11.33 \mathrm{cb}$ & $11.22 \mathrm{~b}$ & $2.67 \mathrm{bc}$ & $3.00 \mathrm{~b}$ & $3.00 \mathrm{~b}$ & $2.89 \mathrm{ab}$ & $2.33 \mathrm{c}$ & $2.76 \mathrm{c}$ & $3.00 \mathrm{~b}$ & $2.70 \mathrm{~b}$ \\
\hline & Mean & $9.00 \mathrm{~cd}$ & $11.33 \mathrm{~b}$ & $11.33 \mathrm{~b}$ & $10.55 \mathrm{~b}$ & $9.11 \mathrm{~d}$ & $11.00 \mathrm{~b}$ & $11.04 \mathrm{~b}$ & $10.38 \mathrm{~b}$ & $1.92 \mathrm{~b}$ & $2.56 \mathrm{ab}$ & $2.56 \mathrm{ab}$ & $2.35 \mathrm{~b}$ & $1.81 \mathrm{c}$ & $2.49 \mathrm{~b}$ & $2.73 \mathrm{~b}$ & $2.34 \mathrm{~b}$ \\
\hline \multicolumn{2}{|c|}{ Water quantity mean } & $9.00 \mathrm{~b}$ & $11.00 \mathrm{a}$ & $11.33 \mathrm{a}$ & $\begin{array}{ll}----- \\
\end{array}$ & $9.01 \mathrm{~b}$ & $10.86 \mathrm{a}$ & $11.24 \mathrm{a}$ & $\begin{array}{ll}---- \\
\end{array}$ & $1.87 \mathrm{~b}$ & $2.42 \mathrm{a}$ & $2.51 \mathrm{a}$ & $\begin{array}{ll}----- \\
\end{array}$ & $1.87 \mathrm{~b}$ & $2.48 \mathrm{a}$ & $2.70 \mathrm{a}$ & --.-- \\
\hline
\end{tabular}

* Means within a column or row having the same letters are not significantly different according to Duncan's Multiple Range Test (DMRT) at $5 \%$ level. 
Table (8): Effect of soil texture, kristalon level, water quantity and their interactions on vase life (days) of Polianthes tuberose L. spike during 2007 and 2008 seasons

\begin{tabular}{|c|c|c|c|c|c|c|c|c|c|}
\hline \multirow{3}{*}{$\begin{array}{l}\text { Soil } \\
\text { texture }\end{array}$} & \multirow{3}{*}{$\begin{array}{c}\text { Kristalon } \\
\text { Level } \\
\text { (g/bag) }\end{array}$} & \multicolumn{4}{|c|}{ First season: 2007} & \multicolumn{4}{|c|}{ Second season: 2008} \\
\hline & & & & & Water q & (ml/bag) & & & \\
\hline & & 100 & 150 & 200 & Mean & 100 & 150 & 200 & Mean \\
\hline \multirow{4}{*}{ Sandy } & 0.0 & $5.20 \mathrm{f}$ & $5.20 \mathrm{f}$ & $6.50 \mathrm{e}$ & $5.63 \mathrm{c}$ & $5.20 \mathrm{f}$ & $5.20 \mathrm{f}$ & $5.63 \mathrm{fe}$ & $5.34 \mathrm{e}$ \\
\hline & 2.0 & $5.20 \mathrm{f}$ & $6.07 \mathrm{ef}$ & $6.93 \mathrm{ed}$ & $6.07 \mathrm{c}$ & $5.85 \mathrm{ef}$ & $6.50 \mathrm{e}$ & $6.93 \mathrm{ed}$ & $6.43 \mathrm{~d}$ \\
\hline & 4.0 & $6.93 \mathrm{ed}$ & $7.51 \mathrm{de}$ & $8.67 \mathrm{~cd}$ & $7.70 \mathrm{~b}$ & $7.80 \mathrm{~d}$ & $7.80 \mathrm{~d}$ & $9.10 \mathrm{c}$ & $8.23 \mathrm{c}$ \\
\hline & Mean & $5.78 \mathrm{c}$ & $6.26 \mathrm{c}$ & $7.37 \mathrm{bc}$ & $6.47 \mathrm{~b}$ & $6.28 \mathrm{~d}$ & $6.50 \mathrm{~d}$ & $7.22 \mathrm{ed}$ & $6.67 \mathrm{~b}$ \\
\hline \multirow{4}{*}{ Loamy } & 0.0 & $6.50 \mathrm{e}$ & $6.50 \mathrm{e}$ & $7.80 \mathrm{~d}$ & $6.93 \mathrm{~b}$ & $7.15 \mathrm{de}$ & $7.38 \mathrm{de}$ & $8.50 \mathrm{~cd}$ & $7.68 \mathrm{~cd}$ \\
\hline & 2.0 & $7.37 \mathrm{de}$ & $11.70 \mathrm{a}$ & $10.83 \mathrm{ba}$ & $9.97 \mathrm{a}$ & $8.16 \mathrm{dc}$ & $11.70 \mathrm{a}$ & $11.70 \mathrm{a}$ & $10.52 \mathrm{a}$ \\
\hline & 4.0 & $9.53 \mathrm{cb}$ & $10.40 \mathrm{~b}$ & $10.40 \mathrm{~b}$ & $10.11 \mathrm{a}$ & $9.10 \mathrm{c}$ & $10.40 \mathrm{~b}$ & $10.40 \mathrm{~b}$ & $9.97 \mathrm{ba}$ \\
\hline & Mean & $7.80 \mathrm{~b}$ & $9.53 \mathrm{a}$ & $9.68 \mathrm{a}$ & $9.00 \mathrm{a}$ & $8.14 \mathrm{cb}$ & $9.83 \mathrm{a}$ & $10.20 \mathrm{a}$ & $9.39 \mathrm{a}$ \\
\hline \multirow{4}{*}{ Calcareous } & 0.0 & $6.50 \mathrm{e}$ & $6.50 \mathrm{e}$ & $7.80 \mathrm{~d}$ & $6.93 \mathrm{~b}$ & $6.93 \mathrm{ed}$ & $7.37 \mathrm{de}$ & $7.80 \mathrm{~d}$ & $7.37 \mathrm{dc}$ \\
\hline & 2.0 & $7.80 \mathrm{~d}$ & $10.83 \mathrm{ba}$ & $10.40 \mathrm{~b}$ & $9.68 \mathrm{a}$ & $7.37 \mathrm{de}$ & $10.40 \mathrm{~b}$ & $10.40 \mathrm{~b}$ & $9.39 \mathrm{~b}$ \\
\hline & 4.0 & $9.10 \mathrm{c}$ & $9.97 \mathrm{bc}$ & $10.40 \mathrm{~b}$ & $9.82 \mathrm{a}$ & $8.79 \mathrm{~cd}$ & $9.10 \mathrm{c}$ & $10.40 \mathrm{~b}$ & $9.43 \mathrm{~b}$ \\
\hline & Mean & $7.80 \mathrm{~b}$ & $9.10 \mathrm{a}$ & $9.53 \mathrm{a}$ & $8.81 \mathrm{a}$ & $7.70 \mathrm{c}$ & $8.96 \mathrm{~b}$ & $9.53 \mathrm{a}$ & $8.73 \mathrm{a}$ \\
\hline Nater al & & $7.13 \mathrm{~b}$ & $8.30 \mathrm{a}$ & $8.86 \mathrm{a}$ &  & $7.37 \mathrm{~b}$ & $8.43 \mathrm{a}$ & $8.98 \mathrm{a}$ & 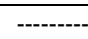 \\
\hline
\end{tabular}

${ }^{*}$ Means within a column or row having the same letters are not significantly different according to Duncan's Multiple Range Test (DMRT) at $5 \%$ level. 
Table (10): Effect of soil texture, kristalon level, water quantity and their interactions on the replacement clump fresh and dry weights of Polianthes tuberosa L. plant during 2007 and 2008 seasons

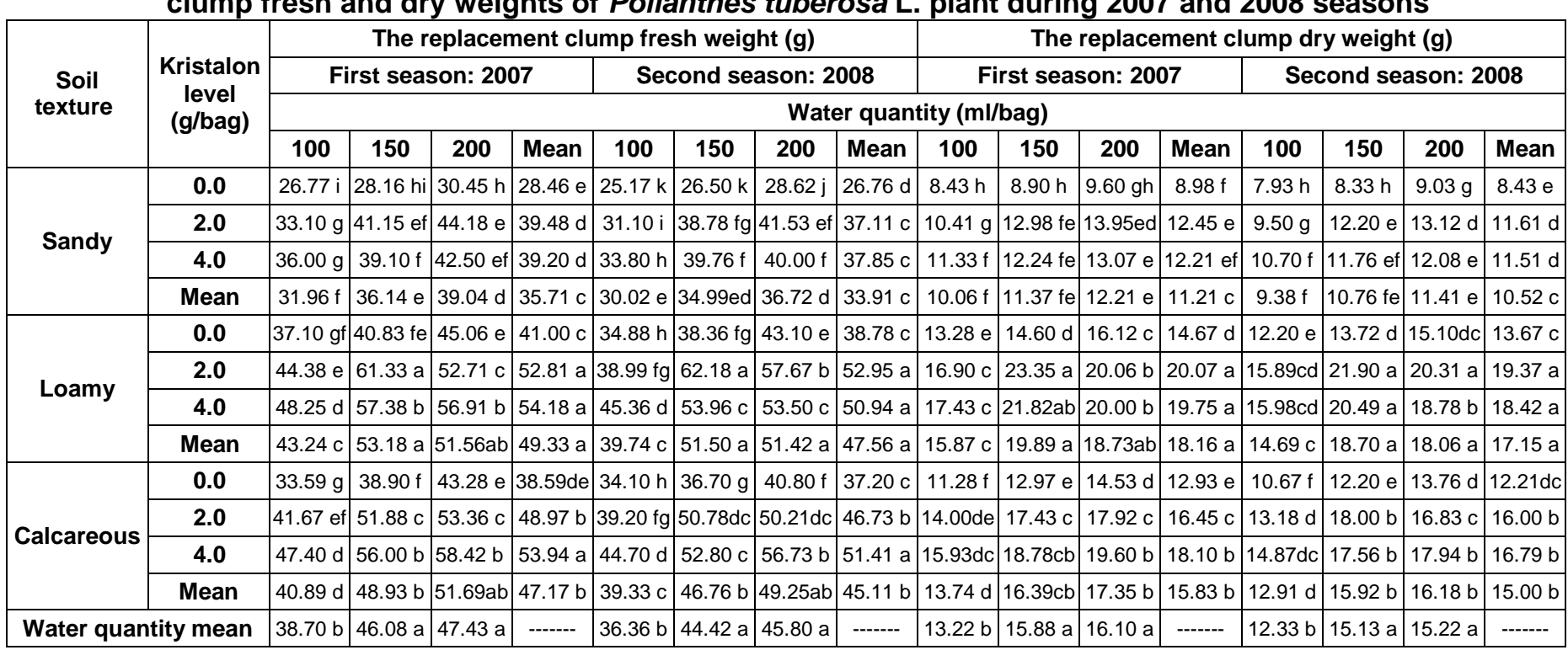

* Means within a column or row having the same letters are not significantly different according to Duncan's Multiple Range Test (DMRT) at $5 \%$ level. 
Table (11): Effect of soil texture, kristalon level, water quantity and their interactions on pigments content (mg/g fresh weight) in the leaves of Polianthes tuberosa L. plant during 2008 season

\begin{tabular}{|c|c|c|c|c|c|c|c|c|c|c|c|c|c|}
\hline \multirow{3}{*}{$\begin{array}{l}\text { Soil } \\
\text { texture }\end{array}$} & \multirow{3}{*}{$\begin{array}{c}\text { Kristalon } \\
\text { level } \\
\text { (g/bag) }\end{array}$} & \multicolumn{4}{|c|}{ Chlorophyll a } & \multicolumn{4}{|c|}{ Chlorophyll b } & \multicolumn{4}{|c|}{ Carotenoids } \\
\hline & & \multicolumn{12}{|c|}{ Water quantity (ml/bag) } \\
\hline & & 100 & 150 & 200 & Mean & 100 & 150 & 200 & Mean & 100 & 150 & 200 & Mean \\
\hline \multirow{4}{*}{ Sandy } & 0.0 & 0.889 & 0.910 & 0.934 & 0.991 & 0.456 & 0.481 & 0.501 & 0.479 & 0.571 & 0.596 & 0.625 & 0.597 \\
\hline & 2.0 & 0.943 & 1.004 & 0.986 & 0.978 & 0.468 & 0.523 & 0.547 & 0.513 & 0.583 & 0.671 & 0.698 & 0.651 \\
\hline & 4.0 & 0.987 & 1.028 & 1.073 & 1.029 & 0.559 & 0.588 & 0.610 & 0.586 & 0.602 & 0.638 & 0.651 & 0.630 \\
\hline & Mean & 0.940 & 0.981 & 0.998 & 0.973 & 0.494 & 0.531 & 0.553 & 0.526 & 0.585 & 0.635 & 0.658 & 0.626 \\
\hline \multirow{4}{*}{ Loamy } & 0.0 & 0.918 & 0.938 & 0.958 & 0.938 & 0.506 & 0.527 & 0.546 & 0.526 & 0.688 & 0.707 & 0.718 & 0.704 \\
\hline & 2.0 & 0.990 & 1.112 & 1.095 & 1.066 & 0.551 & 0.733 & 0.598 & 0.627 & 0.697 & 0.756 & 0.731 & 0.728 \\
\hline & 4.0 & 1.003 & 1.027 & 1.079 & 1.036 & 0.601 & 0.697 & 0.654 & 0.651 & 0.721 & 0.745 & 0.699 & 0.722 \\
\hline & Mean & 0.970 & 1.026 & 1.044 & 1.013 & 0.553 & 0.652 & 0.599 & 0.601 & 0.702 & 0.736 & 0.716 & 0.718 \\
\hline \multirow{4}{*}{ Calcareous } & 0.0 & 0.907 & 0.928 & 0.961 & 0.932 & 0.476 & 0.495 & 0.511 & 0.494 & 0.596 & 0.620 & 0.648 & 0.621 \\
\hline & 2.0 & 0.916 & 0.967 & 0.993 & 0.959 & 0.501 & 0.535 & 0.556 & 0.531 & 0.631 & 0.691 & 0.676 & 0.666 \\
\hline & 4.0 & 0.952 & 1.015 & 0.984 & 0.984 & 0.541 & 0.697 & 0.658 & 0.632 & 0.661 & 0.687 & 0.697 & 0.681 \\
\hline & Mean & 0.925 & 0.970 & 0.979 & 0.958 & 0.506 & 0.576 & 0.575 & 0.552 & 0.629 & 0.666 & 0.674 & 0.656 \\
\hline \multicolumn{2}{|c|}{ Water quantity mean } & 0.945 & 0.992 & 1.007 & ----- & 0.518 & 0.586 & 0.576 & ----- & 0.639 & 0.679 & 0.683 & ----- \\
\hline
\end{tabular}


Shahin, S.M. et al.

Table (12): Effect of soil texture, kristalon level, water quantity and their interactions on total carbohydrates, N, P and $\mathrm{K}$ percentages in the leaves of Polianthes tuberosa L. plant during 2008 season

\begin{tabular}{|c|c|c|c|c|c|c|c|c|c|c|c|c|c|c|c|c|c|}
\hline \multirow{3}{*}{$\begin{array}{c}\text { Soil } \\
\text { texture }\end{array}$} & \multirow{3}{*}{$\begin{array}{c}\text { Kristalon } \\
\text { level } \\
\text { (g/bag) }\end{array}$} & \multicolumn{4}{|c|}{ Total carbohydrates } & \multicolumn{4}{|c|}{$\mathbf{N}$} & \multicolumn{4}{|c|}{$\mathbf{P}$} & \multicolumn{4}{|c|}{$k$} \\
\hline & & \multicolumn{16}{|c|}{ Water quantity (ml/bag) } \\
\hline & & 100 & 150 & 200 & Mean & 100 & 150 & 200 & Mean & 100 & 150 & 200 & Mean & 100 & 150 & 200 & Mean \\
\hline \multirow{4}{*}{ Sandy } & 0.0 & 19.68 & 21.23 & 22.46 & 21.12 & 0.78 & 0.86 & 0.93 & 0.86 & 0.18 & 0.21 & 0.27 & 0.22 & 0.89 & 0.97 & 1.07 & 0.98 \\
\hline & 2.0 & 20.90 & 22.85 & 25.17 & 22.97 & 0.82 & 0.97 & 1.04 & 0.94 & 0.20 & 0.28 & 0.29 & 0.26 & 1.02 & 1.28 & 1.36 & 1.22 \\
\hline & 4.0 & 22.38 & 23.77 & 25.59 & 23.91 & 0.91 & 1.18 & 1.32 & 1.14 & 0.24 & 0.27 & 0.28 & 0.26 & 1.13 & 1.33 & 1.38 & 1.28 \\
\hline & Mean & 20.99 & 22.62 & 24.41 & 22.67 & 0.84 & 1.00 & 1.10 & 0.98 & 0.21 & 0.25 & 0.28 & 0.25 & 1.01 & 1.19 & 1.27 & 1.16 \\
\hline \multirow{4}{*}{ Loamy } & 0.0 & 22.67 & 24.34 & 25.69 & 24.23 & 1.12 & 1.20 & 1.31 & 1.21 & 0.23 & 0.26 & 0.27 & 0.25 & 2.03 & 2.40 & 2.46 & 2.30 \\
\hline & 2.0 & 23.56 & 28.41 & 27.37 & 26.45 & 1.38 & 1.86 & 1.52 & 1.59 & 0.26 & 0.31 & 0.30 & 0.29 & 2.12 & 2.91 & 2.73 & 2.59 \\
\hline & 4.0 & 25.09 & 26.32 & 26.55 & 25.99 & 1.47 & 1.73 & 1.63 & 1.61 & 0.30 & 0.30 & 0.28 & 0.29 & 2.31 & 2.80 & 2.58 & 2.56 \\
\hline & Mean & 23.77 & 26.36 & 26.54 & 25.56 & 1.32 & 1.60 & 1.49 & 1.47 & 0.26 & 0.29 & 0.28 & 0.28 & 2.15 & 2.70 & 2.59 & 2.48 \\
\hline \multirow{4}{*}{ Calcareous } & 0.0 & 20.85 & 22.34 & 24.10 & 22.43 & 1.10 & 1.30 & 1.43 & 1.28 & 0.20 & 0.23 & 0.25 & 0.23 & 1.46 & 1.76 & 1.92 & 1.71 \\
\hline & 2.0 & 23.15 & 25.75 & 26.89 & 25.26 & 1.29 & 1.70 & 1.79 & 1.59 & 0.22 & 0.30 & 0.31 & 0.28 & 1.58 & 2.28 & 2.36 & 2.07 \\
\hline & 4.0 & 25.68 & 27.74 & 26.10 & 26.51 & 1.50 & 1.75 & 1.81 & 1.69 & 0.25 & 0.27 & 0.30 & 0.27 & 1.73 & 2.33 & 2.17 & 2.08 \\
\hline & Mean & 23.23 & 25.28 & 25.70 & 24.73 & 1.30 & 1.58 & 1.68 & 1.52 & 0.22 & 0.27 & 0.29 & 0.26 & 1.59 & 2.12 & 2.15 & 1.95 \\
\hline \multicolumn{2}{|c|}{ Water quantity mean } & 22.66 & 24.75 & 25.55 & \begin{tabular}{|l|}
------ \\
\end{tabular} & 1.15 & 1.39 & 1.42 & \begin{tabular}{|l}
------ \\
\end{tabular} & 0.23 & 0.27 & 0.28 & \begin{tabular}{|l}
------ \\
\end{tabular} & 1.58 & 2.00 & 2.00 & 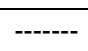 \\
\hline
\end{tabular}


J. Agric. Sci. Mansoura Univ., 34 (4), April, 2009

3743 